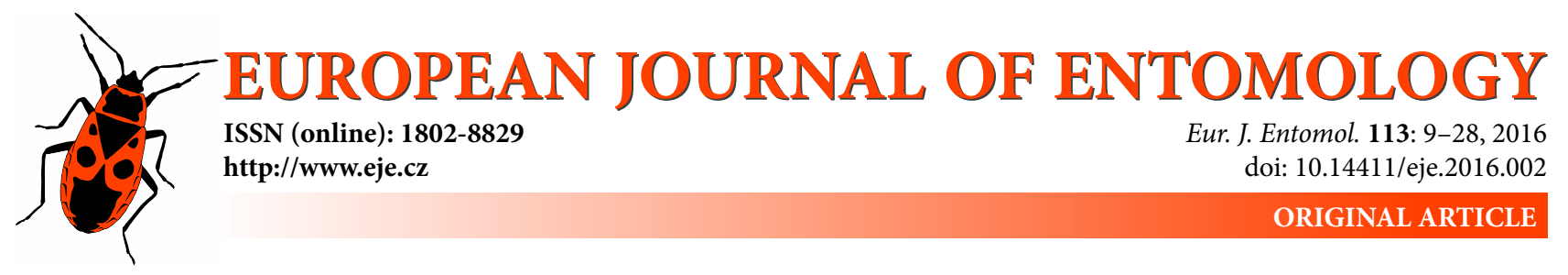

\title{
A revision of the cleptoparasitic bee genus Coelioxys (Hymenoptera: Megachilidae) from Australia
}

\author{
Léo CoRREIA dA ROCHA-FILHO \\ York University, Department of Biology, 4700 Keele St, Toronto, ON M3J 1P3, Canada; e-mail: correiadarocha@yahoo.com.br
}

Key words. Taxonomy, revision, new species, new synonyms, Apoidea, Megachilidae, Australasia, cleptoparasite, Coelioxys

Abstract. The Australian species of the genus Coelioxys Latreille are revised. Six species are recognized: Coelioxys albolineata Cockerell, 1905; Coelioxys froggatti Cockerell, 1911; Coelioxys reginae Cockerell, 1905; Coelioxys weinlandi Schulz, 1904 and two new species: Coelioxys julia sp. n. and Coelioxys tasmaniana sp. n. Three names are synonymized: Coelioxys biroi Friese, 1909 syn. n. and Coelioxys albolineata darwiniensis Cockerell, 1929 syn. n. under Coelioxys albolineata, and Coelioxys victoriae Rayment, 1935 syn. n. under Coelioxys froggatti. Species descriptions and redescriptions, illustrations, distribution maps, floral records and a key to both sexes of all species are provided.

ZooBank Article LSID: 8E61B6E3-BA51-4583-A68F-37EDF62ECF8C

\section{INTRODUCTION}

The bee fauna from Australia is one of the most diverse and distinctive with a total of 1,651 species currently recognized and distributed among 64 genera (Australian Faunal Directory, 2006; Batley \& Hogendoorn, 2009; Gonzalez et al., 2013). Most of this diversity is found within the family Colletidae which represents $53.2 \%$ of all bee species in the country and also the most genera - 32 (Australian Faunal Directory, 2006). Despite this highly diverse melissofauna, the parasitic bee fauna in Australia is poorly represented, with only two social parasites of the genus Inquilina Michener, 1961 and four genera of cleptoparasitic bees: Sphecodes Latreille, 1804 (Halictidae), Coelioxys Latreille, 1809 (Megachilidae), Nomada Scopoli, 1770 and Thyreus Panzer, 1806 (Apidae), the latter being the most species-rich, but still with only ten species (Australian Faunal Directory, 2006). Michener (1965) pointed out that the cuckoo bee fauna from Australia and South Pacific regions would be scarcer than in any major part of the world because most of the Australian bees are colletids, a family in which only five parasitic species of Hylaeus (Nesoprosopis) Perkins, 1899 are known, all from Hawaii (Daly \& Magnacca, 2003).

Considering that most Coelioxys spp. females parasitize nests of species of Megachile Latreille, 1802 (Michener, 2007), Cockerell (1905) mentioned F. Smith's observation about how singular it would be if Coelioxys was absent in Australia where Megachile is so abundant. This idea was also mentioned by Michener (1965) who stressed the surprising scarcity of Australian Coelioxys species compared to the abundance of its host genus. According to the Australian Faunal Directory (2006) database, it is particularly noteworthy that Megachile is represented in Australia by 154 species whereas there are only six names registered for Coelioxys.

Cockerell (1905) described two species of Coelioxys: $C$. albolineata and $C$. reginae, from Australia and emphasized that these were the first records of the genus for the country. Subsequently, Friese (1909) studied Coelioxys specimens from Papua New Guinea and Cairns, Queensland and described $C$. albiceps as the third species of the genus recorded from Australia. In 1911, Cockerell (1911) described a fourth Australian Coelioxys, from Victoria: C. froggatti, and provided a key for the species of the genus from Australia, New Guinea and the Solomon Islands. In the same article, Cockerell (1911) synonymized C. albiceps Friese under $C$. weinlandi Schulz, 1904, which had been described by Schulz (1904) from a female from Finschhafen, Papua New Guinea. Based on a male from Port Darwin, Northern Territory, Australia, Cockerell (1929) described C. albolineata darwiniensis, treating it as a variety of C. albolineata, solely because of the dark red (rather than black) colouration on its legs and mesosoma. However, he noted that the specimen may be no more than a colour-variety of C. albolineata. The most recent paper dealing with species description of Coelioxys from Australia is that of Rayment (1935) who described C. victoriae from a female collected in Gunbower, Victoria. Michener (1965), on a revision, at the generic and subgeneric levels, of the bees of the Australian and South Pacific regions, listed five species from 
Australia: C. albolineata, C. darwiniensis (raised to species level), C. froggatti, C. reginae and C. victoriae. He did not include $C$. weinlandi but added $C$. dispersa Cockerell, 1911 and $C$. peregrinata Cockerell, 1911 from the Solomon Islands, C. biroi Friese, 1909 from New Guinea and C. smithii Dalla Torre, 1896 from Indonesia. Since that article no major taxonomic study has been carried out for the genus Coelioxys in Australia. In the light of the above, the aim of this study is to provide a revision of the Australian species of Coelioxys, a key to separate the species of the genus, descriptions of two new species, redescriptions of the other species, three synonymies as well as floral records and distribution maps.

\section{MATERIAL AND METHODS}

\section{Taxonomic descriptions}

The specimens studied belong to the following institutions: Australia - Australian Museum, Sydney (AMS); Australian National Insect Collection, Canberra (ANIC); Queensland Museum, Brisbane (QM); South Australian Museum, Adelaide (SAM); Victoria Museum, Melbourne (MVMA); Western Australian Museum, Perth (WAM); Canada - Packer Collection York University, Toronto (PCYU); United States - Academy of Natural Sciences, Philadelphia (ANSP); American Museum of Natural History, New York (AMNH); California Academy of Sciences, San Francisco (CAS); Museum of Comparative Zoology, Harvard University, Cambridge (MCZ). All type specimens were studied while visiting the collections where they are deposited as follows: C. froggatti - National Museum of Natural History, Smithsonian Institute, Washington D.C., USA (USNM); C. albiceps and $C$. biroi - Museum für Naturkunde, Humboldt-Universität zu Berlin, Berlin, Germany (ZMHB); C. albolineata, $C$. dispersa, C. reginae and C. weinlandi-Natural History Museum, London, UK (BMNH).

The terminology used for the species descriptions and redescriptions follows Mitchell (1973). All measurements are in millimeters $(\mathrm{mm})$. The abbreviations used were $\mathrm{F}, \mathrm{T}$ and $\mathrm{S}$ for flagellomeres, metasomal terga and sterna, respectively.

The hidden sterna and genitalia of males were dissected and cleared in a $10 \% \mathrm{KOH}$ solution, mounted on cavity slides with glycerine and then examined and photographed. Images were taken using a Visionary Digital BK Plus imaging system using a Canon EOS 40D digital SLR camera and processed with Adobe Photoshop(C). Label data of type specimens were transcribed ipsis litteris. Different labels on the pin of the same specimen were cited between quotation marks ("')); commas (,) were used to indicate breaks in text and a slash (/) to specify information on the underside of the label. Illegible words were mentioned as "[Illegible]" and misspelled words were followed by "[sic]" and the corrected spelling between brackets.

\section{Floral, host and locality records}

Data on floral, bee host and locality records were taken from specimen labels. Distribution maps were obtained with the assistance of the program DIVA-GIS 7.5 (DIVA-GIS 2015).

\section{TAXONOMY}

\section{Genus Coelioxys Latreille, 1809}

Latreille, 1809: 166.

Species within this genus are characterized by the produced axilla and presence of omaular carina. In females the metasoma is conical and lacks scopa whereas in males there are two pairs of dorsal and ventral processes apically in the sixth tergum.

Six species of Coelioxys are recognized for Australia including two new ones: $C$.julia sp. n. and C.tasmaniana sp. n. Two species, $C$. julia sp. n. and $C$. weinlandi, belong to the subgenus Torridapis Pasteels, 1977. The other known species: $C$. albolineata, $C$. froggatti and $C$. reginae, have traditionally been considered to belong to the subgenus Coelioxys s. str. Latreille, 1809 (Michener, 1965, 2007; Australian Faunal Directory, 2006; Ascher \& Pickering, 2015). Nonetheless, an ongoing morphological phylogenetic analysis shows that $C$. (Coelioxys s. str.) is clearly paraphyletic and the three Australian species previously assigned to it as well as the new species $C$. tasmaniana sp. n. comprise two monophyletic subgenera that will be described (Rocha-Filho \& Packer, in prep.). Hence, those four species are not placed under a subgeneric name in this paper.

Three species are placed in synonymy: $C$. biroi syn. n. and $C$. darwiniensis syn. n. under $C$. albolineata and $C$. victoriae syn. n. under $C$. froggatti (for details see species redescriptions section). A key to both sexes of the Australian species of Coelioxys is provided. Regarding the distribution records, C. tasmaniana is the only species recorded in Tasmania where it is endemic. Coelioxys froggatti is the only species known from Southern Australia and Victoria and most of its records are from southern areas of the latter state and Western Australia. Both C. albolineata and $C$. reginae occur predominantly along the Queensland coast, with some records from the northern parts of the Northern Territory and also in Papua New Guinea. The new species $C$. julia is only known from southern Queensland and northeastern New South Wales; Coelioxys weinlandi is recorded from the northern Queensland coast and also occur in Papua New Guinea.

\section{Key to the Coelioxys species recorded in Australia}

1 Compound eyes bare (Fig. 11B); F1 less than half as long as F2 (Fig. 9B); mesosoma mostly covered with black hairs (Fig. 11A); metanotum expanded basally, forming a deep sulcate area (Fig. 11C); axilla long, free part longer than attached part, conspicuously curved apically (Fig. 11C); wings dark, heavily infuscate with violet reflections (Figs 9A, 11A). Female: T6 and S6 greatly elongate, more than $2 \times$ longer than broad (Figs 9E, 11E); S5 greatly elongate towards apex, more than $1.5 \times$ longer than broad (Fig. 9A); lateral margins of S6 with fringe of short, plumose, brownish hairs (Figs 9E, 11E). Male: Hypostomal area lacking concavity (Figs 9I, 11G); gena unmodified, not excavated along posterior margin of compound eye (Figs 9I, 11G); S4 flattened medially, forming two robust processes apically (Figs 9K, 11J) ....................... 2

- Compound eyes hairy (Figs 1G, 7B); F1 more than half as long as F2 length (Fig. 1B); mesosoma with white hairs forming marginal lines, lacking black hairs (Figs 3C, 5C); metanotum neither expanded basally nor sulcate; axilla short, attached part shorter than free part (Figs 1C, 5C); wings subhyaline (Figs 1A, 7A). Female: T6 and S6 elongate, less than $1.5 \times$ longer than broad (Figs 1D, 3D); S5 triangular, not elongate towards apex, less than $1 \times$ longer than broad (Figs 3A, $5 \mathrm{~A}$ ); lateral margins of $\mathrm{S} 6$ lacking fringe (Figs 5E, 7E). Male: Hypostomal concavity present (Figs $3 \mathrm{G}, 5 \mathrm{H}$ ); gena excavated 
along lower half of posterior margin of compound eye (Figs $1 \mathrm{H}, 7 \mathrm{H})$; S4 unmodified, not flattened medially, apical margin entire (Figs 5J, 7J)

2 Mesoscutum moderately densely punctate, with larger, elliptical punctures anteriorly, smaller, circular punctures throughout; interspaces smooth, polished and larger than diameter of smaller punctures (Fig. 9C); posterior margin of mesoscutum lacking a sharp medial dorsal carina (Fig. 9C); vertexal and occipital areas covered with suberect, long, thin, black hairs (Fig. 9C); ventral surface of mesepisternum, coxae and trochanters covered with white hairs. Females: Apical margin of clypeus simple, not produced medially (Fig. 9B); anterior margin of mesoscutum lacking two sublateral circular spots but with inconspicuous lines of suberect white hairs (Fig. 9C); apical fasciae of T2-T5 inconspicuous (Fig. 9D); lateral carinae on T6 evanescent subapically, stronger and forming a short U-shaped carina apically (Fig. 9E); lateral margins of S2-S4 lacking sparse appressed white hairs (Fig. 9F). Male: Apical margins of terga lacking bands of white hairs (Fig. 9G); postgradular grooves of T2-T5 not fasciate; lateral teeth of T6 long, acute apically (Fig. 9J); S4 apical margin with two inconspicuously elevated processes which are shorter than the distance that separates them (Fig. 9K).

.Coelioxys julia Rocha-Filho sp. n.

- Mesoscutum sculpturing very coarse, rugose, small punctures intermixed with few larger, elliptical punctures throughout (Fig. 11C); posterior margin of mesoscutum carinate, carina sharply elevated (Fig. 11C); vertexal and occipital areas covered with subappressed, plumose, white hairs (Fig. 11C); ventral surface of mesepisternum, coxae and trochanters covered with dark brown hairs. Females: Apical margin of clypeus produced medially, its margin truncate (Fig. 11B); anterior margin of mesoscutum with two sublateral circular spots of subappressed white hairs (Fig. 11C) or dense fascia of appressed white hairs interrupted medially; apical fasciae of T2-T5 conspicuous, slightly diluted medially (Fig. 11D); lateral carinae on T6 strong throughout, meeting each other towards apex and forming an elongate U-shape (Fig. 11E); lateral margins of S2-S4 with sparse appressed white hairs forming a circular area (Fig. 11F). Male: Apical margins of terga with thick bands of white hairs (Fig. 11G); postgradular grooves of T2-T6 conspicuously fasciate (Fig. 11G); lateral teeth of T6 short, blunt apically (Fig. 11I); S4 apical margin with two conspicuously elevated processes which length is longer than the distance that separates them (Fig. 11J)...

Coelioxys weinlandi Schulz

3 Vertexal area, mesoscutum and mesoscutellum sparsely punctate, interspaces between punctures shining, larger than puncture diameter (Fig. 1C); mesoscutellum posteriorly obtusely produced, conspicuously emarginate and upwardly oriented (Fig. 1C). Female: T6 dorsal carina subapically inconspicuously elevated, weak (Fig. 1D); S6 elongate, much longer than broad, strongly flexed downwards, subapical notches vestigial, obsolescent (Fig. 1D). Male: Genal excavation linear, anterior and posterior margins nearly parallel, more than $4 \times$ longer than broad (Fig. 1H); T6 dorsal processes long, triangular, acute apically (Fig. 1I)

Coelioxys albolineata Cockerell

- Vertexal area, mesoscutum and mesoscutellum densely punctate (Fig. 5C) to coarsely punctate to areolate (Figs 3C, 7C), interspaces between punctures always less than puncture diameter (Figs 5C, 7C); mesoscutellum posteriorly rounded, not produced and not upwardly oriented (Figs 3C, 5C). Female: T6 dorsal carina subapically conspicuously elevated, sharp (Figs 5E, 7E); S6 longer than broad, flexed downwards, subapical notches conspicuous (Fig. 5E) or angled (Figs 3D, 7E). Male: Genal excavation enlarged posteriorly, not linear, posterior margin distinctly curved, less than $3.5 \times$ longer than broad (Figs 3G, 5H); T6 dorsal processes elongate, rounded apically (Figs 3H, 7I) or short, broad, rounded apically (Fig. 5I).

4 Mesoscutum sculpturing punctate, never areolate, punctures deep, interspaces between punctures more than one third puncture diameter (Fig. 5C); forewing slightly infuscate on apical half (Fig. 5F); apical fasciae on terga interrupted medially (Fig. 5D); apical fasciae on sterna sparse medially, but never completely interrupted. Female: Compound eye not convex basally (Fig. 5A); S6 conspicuously notched subapically, notches triangular, acute (Fig. 5E). Male: T6 dorsal processes short, broad, broadly rounded apically (Fig. 5I); S4 apical margin and apical rim medially in lateral view distinctly angled, apical margin surface elevated in relation to apical rim (Fig. 5J) .............................. Coelioxys reginae Cockerell

- Mesoscutum sculpturing punctate to areolate, punctures shallow, interspaces between punctures less than one third puncture diameter (Figs 3C, 7C); forewing subhyaline, never infuscate apically (Figs 3A, 7F); apical fasciae on terga complete; apical fasciae on sterna interrupted medially. Female: Compound eye distinctly convex basally (Figs 3A, 7A); lateral margins of S6 angled to subangled subapically, never with conspicuous acute notches (Figs 3D, 7E). Male: T6 dorsal processes elongate, narrow, rounded apically (Figs 3H, 7I); $\mathrm{S} 4$ apical margin and apical rim medially in lateral view not angled, both on same plane (Fig. 7J) ..................................... 5

5 Face covered with appressed plumose hairs (Figs 3B, 3F); ocular hairs short (about $0.07 \mathrm{~mm}$ ) (Fig. 3B); lateral surface of mesepisternum covered with appressed, plumose to scalelike hairs (Fig. 3A); anterior margin of mesoscutellum with two large, elliptical sublateral spots of appressed hairs (Fig. $3 \mathrm{C}$ ), posterior surface of mesoscutellum covered with subappressed, plumose to scale-like hairs (Fig. 3C). Female: Fascia on basal concavity of $\mathrm{T} 1$ composed of appressed, plumose, white hairs intermixed with subappressed, pale setae. Male: Hypostomal concavity covered with very short, white hairs that are slightly longer on the anterior margin (Fig. 3G); postgradular groove of T5 conspicuously fasciate

Coelioxys froggatti Cockerell

- Face covered with suberect elongate hairs (Figs 7B, 7G); ocular hairs long (about $0.12 \mathrm{~mm}$ ) (Fig. 7B); lateral surface of mesepisternum covered with suberect, elongate hairs, never with scale-like hairs (Fig. 7A); anterior margin of mesoscutellum with two slender sublateral spots of suberect hairs (Fig. 7C), posterior surface of mesoscutellum covered with sparse, suberect, elongate, thin hairs (Fig. 7C). Female: Fascia of basal area of $\mathrm{T} 1$ of subappressed, thin, pale setae, lacking plumose hairs (Fig. 7D). Male: Hypostomal concavity covered with sparse, long, whitish hairs curved apically (Fig. 7H); postgradular groove of T5 not fasciate (Fig. 7I) .............

Coelioxys tasmaniana Rocha-Filho sp. n.

\section{Coelioxys albolineata Cockerell, 1905}

(Figs 1A-M, 2)

Coelioxys biroi Friese, 1909: 268-269, syn. n.

Coelioxys albolineata darwiniensis Cockerell, 1929: 8, syn. n.

Diagnosis. Compared to the other Australian species, $C$. albolineata is the only one with an emarginate posterior margin of the mesoscutellum. Additionally, the mesoscutellum is nearly impunctate medially and sparsely punctate 




Fig. 1. Coelioxys albolineata. Female (A-D): A - lateral view; B - frontal view of head; $C$ - dorsal view of mesoscutum and mesoscutellum; $\mathrm{D}$ - dorsal view of T6 and S6. Male (E-M): E - lateral view; F - lateral view (for red colouration of mesosoma); $\mathrm{G}$ - frontal view of head; $\mathrm{H}$ - lateral view of head and mesosoma (for genal excavation and hypostomal concavity); I - dorsal view of T5-T6; J - S5; K - S6; L - S8; $\mathrm{M}$ - genitalia. Scale bar $=1.5 \mathrm{~mm}(\mathrm{~A}-\mathrm{I}) ; 1 \mathrm{~mm}(\mathrm{~J}-\mathrm{M})$. 
towards the lateral margins whereas in other species the mesoscutellum is coarsely and densely punctate throughout. Other diagnostic characteristics of this species are as follows: the S6 shape in females (elongate, strongly flexed downwards, with two vestigial, inconspicuous notches subapically contrasting to the acute notches in $C$. reginae and the angled lateral margins in both $C$. froggatti and $C$. tasmaniana); the genal excavation in males (linear, not enlarged posteriorly as in males of the other species); the shape of T6 dorsal processes in males (triangular, acute apically, parallel to one another rather than broad and rounded apically in $C$. reginae and elongate, narrow and broad apically in both $C$. froggatti and $C$. tasmaniana). The impunctate and emarginate mesoscutellum is also observed in another species from the Australasian region, $C$. dispersa from Solomon Islands, but this species has not been recorded from Australia.

Redescription, female. Measurements (one specimen, Townsville, Cape Ferguson, Qld., ANIC). Body length: $6.98 \mathrm{~mm}$; forewing length: $4.27 \mathrm{~mm}$; head width: $1.77 \mathrm{~mm}$.

Colouration. Black except as follows: Antenna, mandible but apex, labrum, tegula, legs, sterna dark brown; wings subhyaline; veins brownish. In some specimens the mesoscutum, mesopleuron and legs are dark red. In some specimens with black colouration throughout the legs are brownish.

Pubescence. White, appressed/subappressed on: Paraocular area, supraclypeal area, clypeus, fringe on apical margin of clypeus, gena, half basal of mandible, pronotum, lateral margins of mesoscutum, mesepisternum, mesopleuron, legs, basal fascia on T1, apical fascia on sterna. Ocular hairs whitish and long (about $0.10 \mathrm{~mm}$ ). Scattered, suberect, slender, whitish setae on paraocular area and supraclypeal area. Upper paraocular area hairs long, white distinct from those of adjacent regions, oriented mesad, apices of some from each side almost meeting medially. Slender, subappressed, short, yellowish setae and scattered, long, thin, yellowish setae on dorsal surface of mandible. Slender, suberect, whitish setae arising from punctures on vertex and mesoscutum. Thick, yellow setae on tarsi. Appressed, plumose, white hairs on two sublateral spots between mesoscutellum and mesoscutum, laterally on subaxilla, lateral bands on $\mathrm{T} 1$, on apical fasciae of $\mathrm{T} 1-$ T5 and elliptical tufts on lateral margins of T6. Erect, long, thin pale hairs on posterior surface of mesoscutellum and metanotum. Lateral margins of S6 basally with suberect, plumose pale hairs.

Surface sculpture. Ocellar area densely punctate; vertex moderately densely punctate; mesoscutum sparsely punctate, punctures small, circular, interspaces shining, much larger than puncture diameter; mesoscutellum shining, nearly impunctate medially, sparsely punctate laterally, interspaces shining, much larger than puncture diameter; axilla sparsely punctate, interspaces shining, much larger than puncture diameter; T1 moderately densely punctate laterally, sparsely punctate medially, interspaces among punctures shining, larger than puncture diameter; pregradular areas of T2-T5 moderately densely punctate, interspaces shining, smooth; postgradular areas of T2-T5 shining, sparsely punctate laterally, T6 minutely and moderately densely punctate basally, punctures very small, coarsely punctate apically, some punctures fused one another; S1 punctate; postgradular areas of S2-S4 moderately densely punctate basally, sparsely punctate towards apex, postgradular area of S5 dull, sparsely punctate basally, more densely punctate towards apex, postgradular area of S6 dull, moderately densely punctate basally, imbricate to punctate apically.

Structure. F1 shorter than F2, but longer than half F2 length, subequal to pedicel in length. Ocelloccipital distance longer than ocellocular distance. Compound eye not convex basally. Apical margin of clypeus simple, nearly truncate. Pronotal lamella conspicuously elevated, nearly straight, not forming distinct lobes. Mesoscutellum lacking dorso-median ridge, posterior margin produced medially and conspicuously emarginate, forming two triangular lobes, upwardly oriented; mesoscutellum dorsal and posterior surfaces separated by sharp, carinate edge. Axilla acute, not curved apically, short, detached part much shorter than non-detached part. Forecoxal apical spine-like projections short, flat, rounded apically. T1 basal concavity not carinate. T6 very elongate, tapering towards apex, subacute apically, lateral carinae discrete, incomplete, not reaching the apex, dorsal carina not sharp or conspicuously elevated, separating two obsolescent, shallow, elliptical depressions. S5 elongate, triangular, gradually tapering towards apex. S6 slender, elongate, gradually tapering apically, strongly flexed downwards, lateral margins convergent towards apex, forming two vestigial, obsolete notches subapically, apex subacute, ventral surface convex, not carinate medially.

Redescription, male. Measurements (one specimen, Warraber (Sue) Island, Qld., ANIC). Body length: 6.15 $\mathrm{mm}$; forewing length: $3.96 \mathrm{~mm}$; head width: $1.98 \mathrm{~mm}$.

Colouration. As in female.

Pubescence. As in female except as follows: Face densely covered with appressed, long, white hairs; hypostomal concavity covered with very short, white hairs; genal excavation densely covered with appressed, plumose white hairs. Gradular grooves of T5-T6 conspicuously fasciate with appressed, plumose, white hairs, T4 less distinctly fasciate. Minute, short, suberect, pale setae arising from punctures on T6.

Surface sculpture. As in female except as follows: Postgradular areas of T2 with elliptical, transverse, shining, impunctate area laterally on each side but an elliptical puncture slightly larger than adjacent punctures; postgradular area of T3 indistinct, with elliptical, transverse, shining, impunctate area. T6 moderately densely punctate medially, punctures small, circular, sparsely punctate towards apex, punctures larger, elliptical.

Structure. Hypostomal concavity shallow, shorter than half length of compound eye. Gena deeply excavated along lower margin of eye, its length subequal to half eye length, both anterior and posterior margins of excavation linear, not enlarged anteriorly, excavation much longer than broad, 
its length about $4.5 \times$ longer than its width. Forecoxal apical spine-like projections short, flat, rounded apically. In one male from Saltwater Creek, Qld, the posterior margin of mesoscutellum is not emarginate but it is upwardly oriented and produced medially. Spine-like processes of T5 pointed, separated from tergal surface apically. Basolateral processes of T6 long, acute, cylindrical; dorsal processes long, subacute apically, parallel one another; ventral processes acute apically, cylindrical, slightly divergent. T7 slightly tapering towards apex, rounded apically. Apical margin and apical rim of S4 entire. Apical margin of S5 entire, slightly flattened medially. Apical rim of S5 entire. Gradulus of S5 semicircular. S6 membranous, gradulus indistinct, pregradular areas narrow, elongate, weakly sclerotized on inner margins, strongly sclerotized along outer margins, narrowly acute at base, apical half of pregradular area densely setose, less setose on outer margins, postgradular area transparent medially, broad at base, basal membranous lip rounded. S7 obsolescent, represented by two small sclerites. S8 base elongate, rounded apically, its apex slightly produced medially. Gonocoxa compressed laterally, with some long setae apically, longer than penis valve in length.

Comments. As stressed by Cockerell (1929) C. albolineata darwiniensis differs from $C$. albolineata only by the red colouration on mesoscutum, mesopleuron and legs. No discrepancies were found among specimens of both forms regarding both structural and sculptural characteristics. Additionally, some specimens of $C$. albolineata have brownish legs, an intermediate colour between the dark red observed in C. a. darwiniensis and the dark brown of $C$. albolineata. The two forms are sympatric in the northern parts of the Northern Territory and northern Queensland. However, the single example of C. albolineata from Western Australia is a male with red colouration collected near Mount Bruce, which is more than 2,700 km distant from Darwin, N.T., the closest locality considering the species' currently known distribution.

The syntypes of $C$. biro $i$ were studied and no differences were found when compared to $C$. albolineata specimens and thus the former species was synonymized under the latter. When Friese (1909) described C. biroi based on a female he mentioned three specimens without indicating which was the holotype. From the three specimens he had, two had been collected in New Guinea by Biró (a female from "Simbang, Huon Golf" and a male from "Insel Thiar, Astrolabe Bai") and a female from "Key Inseln" collected by Kühn (apparently Kai Islands in Indonesia). However, in the ZMHB collection, there are six specimens identified as $C$. biroi, three of them (one male labelled as "Type" and two females) from New Britain, Papua New Guinea (labelled as "Neu Pommern" and Neu Britannien" and identified as C. biroi by Friese in 1910). Another female, labelled as from "Key Inseln" and identified by Friese as C. biroi in 1909, seems to be the same species as the other three specimens from New Britain and might be one of the specimens Friese (1909) used for his description. The other two females were collected in 1921 in Buru, Indonesia and



Fig. 2. Distribution records for Coelioxys albolineata.

are different from the others mainly because of their dark wings and are not considered to belong to $C$. albolineata. In light of the above, it is stressed that two of the three specimens used in Friese's (1909) description were not located by the author and that the synonymy is based on the female from "Key Inseln" mentioned in the original description and on the three specimens from New Britain identified by him as C. biroi in 1910. Additionally, in spite of the similarity between $C$. dispersa and $C$. albolineata the former is not being synonymized under the latter since in its male holotype the genal excavation is greatly elongate and linear, almost $6 \times$ longer than broad, whereas in the latter species it is about $4.5 \times$ longer than its width. Also the wings are weakly infuscate on the apical half; the apical fasciae on the terga are broadly interrupted medially and the T6 dorsal processes are rounded apically, rather than subacute apically in $C$. albolineata.

Floral records. Specimens were collected on flowers of Dysophylla stellata (Lour.) Benth. (cited as D. verticillata) (Lamiaceae), Sida subspicata F. Muell. ex Benth (Malvaceae) and Eremophila sp. (Scrophulariaceae).

\section{Host records. None.}

Geographical distribution. Australia (Northern Territory, Queensland, Western Australia), Indonesia (Kai Islands), Papua New Guinea (Central, Morobe, New Britain island) (Fig. 2).

Type material examined. Syntype. Coelioxys albolineata. AUSTRALIA. Queensland. 19 (BMNH), "Mackay", "320", "Queensland., E. Saunders., 93-49.", “Coelioxys albolineata, Ckll TYPE", "Type", "B.M.TYPE, HYM., 17.B.30", "BMNH(E), \#970539". Paratypes. Coelioxys albolineata. AUSTRALIA. Holotype. Coelioxys albolineata darwiniensis. AUSTRALIA.

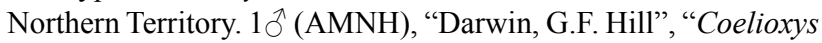
albolineata v. darwiniensis, Ckll.”, “\#2, ac. 24727.”, “\#4, HOLOTYPE”. Syntypes. Coelioxys biroi. PAPUA NEW GUINEA. New Britain. $1 \widehat{\jmath}$ (ZMHB), "Neu Pommern, Kinigunang", "Coelioxys biroi, 1910 Friese Fr. det.", "Type"; 1q (ZMHB), "Neu Britannien, Mus. Godefroy, No. 3937., ehn vend. 3. XII. 19”, “Coelioxys 
biroi, 1910 Friese Fr. det.”; 1 ( Godefroy, No. 395/.". INDONESIA. Kai Islands. 1 + (ZMHB), “Asia Arch., Key Ins., 1900, Kühn”, “Coelioxys biroi, 1909 Friese Fr. det.".

Additional material examined. AUSTRALIA. Northern Territory. $1 \widehat{\delta}(\mathrm{AMNH})$, G.F. Hill, near Darwin; $2 \hat{\jmath}$ (ANIC), Nourlangie Ck., $8 \mathrm{~km} \mathrm{~N}$. of Mt. Cahill. Queensland. $4 q 4 \hat{\jmath}$ (AMS),

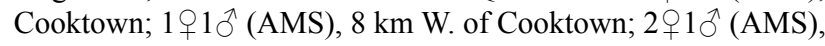
Quarantine Bay, near Cooktown; 1 읏 (AMS), Mission Beach; $1 ㅇ$ (AMS), Allingham, nr Mackay; 1 ㅇ (AMS), Heron Is.; $1 \delta^{\lambda}$ (ANIC), Bundaberg; $1 \overbrace{}^{\lambda}$ (ANIC), Somerset, Cape York; 1 우 (ANIC), Iron Range, Cape York; $1 \delta$ (ANIC), Warraber (Sue), Island; 1 q (ANIC), Cape Ferguson, Townsville; 1 (ANIC), Mt. Webb Nat. Park, 50 km N. Cooktown; $195 \AA$ (ANIC), Mossman; $2 ᄋ$ (ANIC), Cairns; $1 \hat{\jmath}$ (ANIC), 15 W. of Bowen; 1 우 (ANIC), Ellis Beach, N. of Cairns; $9 \hat{\bigcirc}$ (MCZ), Heron Isl. off Gladstone; $1{ }^{\Uparrow}$ (MCZ), Redlynch; 2 워 (MCZ), Coen, C. York; 4 (MCZ),

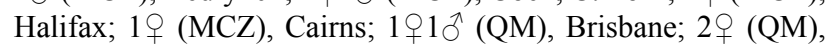
Gordonvale; 1 ( $(\mathrm{QM})$, N. Pine; 1 (QM), Charters Towers; 1 + $(\mathrm{QM})$, "Eclectus" Iron Range; $1 \uparrow 1{ }^{\nearrow}(\mathrm{QM})$, Mackay; 1 ( $(\mathrm{QM})$, Daintree National Park; 2 ( $(\mathrm{QM})$, Gordon Creek area, Claudie Riv. District; $1 \hat{\jmath}(\mathrm{QM})$, Cape Pallarenda; $1 \hat{\delta}(\mathrm{QM})$, Saltwater Creek, N. of Maryborough; $1 \delta^{\lambda}(\mathrm{QM})$, Dunwich; $1 \delta^{\lambda}(\mathrm{QM}), 22$ $\mathrm{km} \mathrm{S}$. of Miriam Vale; 1 + (QM), Yeppoon; 1 ㅇ (SAM), Cairns dist.; $2 \hat{\jmath}$ (SAM), Kuranda; 1 어 (SAM), Pt. Douglas; 4 ㅇ (MVMA), Meringa; 1 ( (MVMA), Meerawa; 1 ㅇ (MVMA), Mia

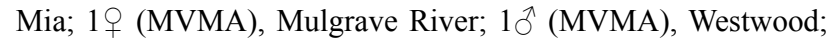
$1 \widehat{\jmath}$ (MVMA), Barron Waters; $1 \hat{\jmath}$ (WAM), $7 \mathrm{mls}$. Wesr Mirani. Western Australia. $1 \jmath^{\hat{\gamma}}$ (WAM), $33 \mathrm{~km}$ SE of Mt Bruce. INDONESIA. Papua. 1 ㅇ (BPBM), New Guinea, SE Biak I.; 2 ㅇ (BPBM), New Guinea: NW Wisselmeren, Enarotadi; 19 (BPBM), West New Guinea, Bokondini, $40 \mathrm{~km}$ N. of Baliem Val.; 1 ㅇ (BPBM), New Guinea: River Tor, 4 km. E. of Hol. Maffen. West Papua. 1 오 (BPBM), New Guinea: Vogelkop: Manokwari. PAPUA NEW GUINEA. Central. 10 (BPBM), New Guinea: Papua C. Dist., Otomata, Plant'n $1 \mathrm{~m}$ E. of Moresby; 1 (QM), Rorona. East New Britain. 1 ( (BPBM), New Britain, Gazelle Pen., Bainings: St.,

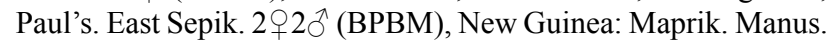
1 우 (BPBM), Bismarck Arch: Manus I., Lorengau; $1 \delta^{\Uparrow}$ (BPBM), Bismarck Arch.: Manus I.: Rossum. Milne Bay. 1 우 $1 \hat{\jmath}$ (BPBM), New Guinea: Papua, Woodlark I. (Murua), Kulumadau Hill. Mo-

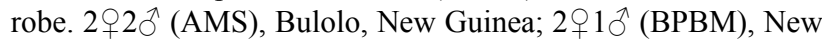
Guinea: Nasawapum, 30 km. NW. of Lae; 1 ㅇ (BPBM), Lae; $1 \delta^{\lambda}$ (BPBM), New Guinea: Gabensis, $32 \mathrm{~km} \mathrm{W.} \mathrm{of} \mathrm{Lae;} 1$ ( $(\mathrm{QM})$,


(BPBM), New Guinea: Tifalmin.

\section{Coelioxys froggatti Cockerell, 1911}

(Figs 3A-M, 4)

Coelioxys victoriae Rayment, 1935: 723, syn. n.

Diagnosis. This species is very similar to $C$. reginae and C. tasmaniana. From the former, C. froggatti can be distinguished by the following list of characteristics: mesoscutum punctate to areolate; lateral surface of mesepisternum covered with appressed, plumose to scale-like hairs; posterior surface of mesoscutellum covered with subappressed, plumose to scale-like hairs; apical fasciae on terga complete. In females the compound eye is distinctly convex basally and the lateral margins of S6 are conspicuously angled subapically. In males the T6 dorsal processes are elongate, narrow and rounded apically and the S4 apical margin and apical rim medially in lateral view are not angled, both surfaces in the same level. The main difference between $C$. froggatti and C. tasmaniana is the hairs on head, mesoscutum and mesepisternum which are appressed in the former species but are distinctly suberect in the second.

Redescription female. Measurements (one specimen, Gunbower, ANIC). Body length: $5.11 \mathrm{~mm}$; forewing length: $3.75 \mathrm{~mm}$; head width: $1.98 \mathrm{~mm}$.

Colouration. Black except as follows: Antenna, mandible but apex, labrum, tegula, legs, T1 throughout, sterna dark brown; wings subhyaline; veins brownish.

Pubescence. White, appressed/subappressed on: Paraocular area, supraclypeal area, clypeus (sparse medially), inconspicuous fringe on apical margin of clypeus, gena, mandible basally, lateral margins of mesoscutum, mesepisternum, legs, basal fascia on T1, apical fascia on sterna (interrupted medially). Ocular hairs whitish and short (about $0.07 \mathrm{~mm}$ ). Scattered, suberect, slender, whitish setae on paraocular area and supraclypeal area. Upper paraocular area hairs long, white distinct from those of adjacent regions, oriented mesad, apices of some from each side almost meeting medially. Scattered, slender, suberect, long, golden setae on dorsal surface of mandible. Slender, suberect, whitish setae arising from punctures on vertex and mesoscutum. Thick, yellow setae on tarsi. Appressed, elongate, plumose to scale-like, white hairs on vertex posteriorly, transverse fascia anteriorly on mesoscutum, two large, elliptical sublateral spots between mesoscutellum and mesoscutum, laterally on subaxilla, mesopleuron, ventral surface of mesepisternum, posterior surface of mesoscutellum, medially on metanotum, lateral bands on T1, on apical fasciae of T1-T5 and elliptical, dense tufts on lateral margins of T6. In some females the transverse fascia anteriorly on mesoscutum is absent or inconspicuous, formed by a few, sparse hairs. The spots of appressed hairs on mesoscutellum vary in size, being larger and more circular in some specimens and narrower in others. Erect, long, thin pale hairs on metanotum. Postgradular area of S6 except subapical area covered with minute, very short, suberect pale setae.

Surface sculpture. Ocellar area coarsely and densely punctate; vertex coarsely and densely punctate but an impunctate, shining area laterally to lateral ocelli; mesoscutum coarsely punctate to areolate, punctures separated by at most one fifth their diameters except less dense medially where interspaces are at most two thirds the puncture diameter; mesoscutellum coarsely and densely punctate to areolate; axilla coarsely and densely punctate; T1 moderately densely punctate, interspaces among punctures shining, larger than puncture diameter; pregradular areas of T2-T5 moderately densely punctate, interspaces shining, smooth; postgradular areas of T2-T5 shining, sparsely punctate laterally, T6 minutely and moderately densely punctate basally, punctures very small, coarsely punctate apically, some punctures fused one another; S1 punctate; postgradular areas of S2-S4 moderately densely punctate basally, sparsely punctate towards apex, postgradular area of S5 dull, sparsely punctate basally, densely punctate apically, postgradular area of S6 dull, moderately densely punctate basally, imbricate to punctate apically. 

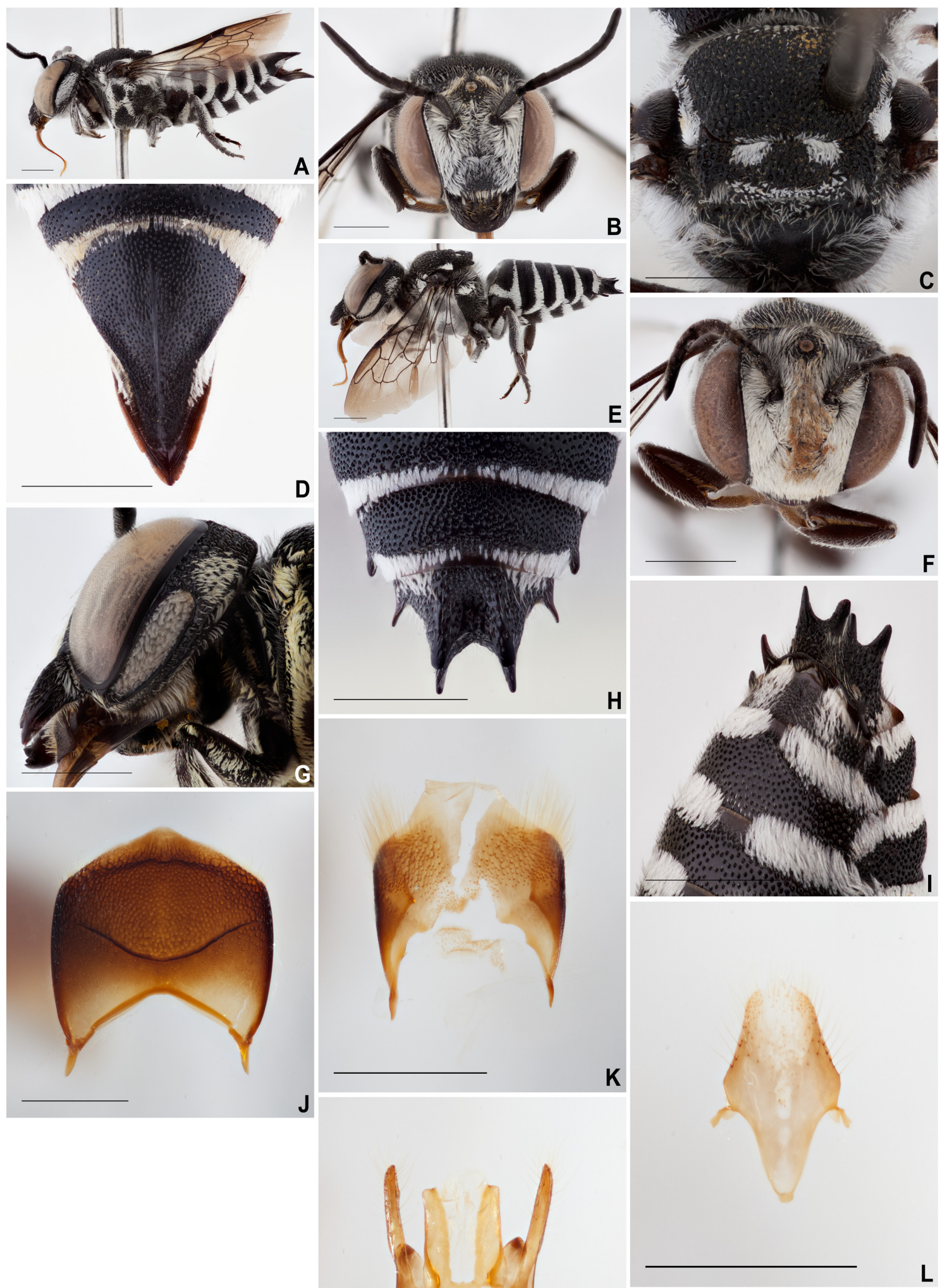

Fig. 3. Coelioxys froggatti. Female (A-D): A - lateral view; $B$ - frontal view of head; $C$ - dorsal view of mesoscutum and mesoscutellum; $D$ - dorsal view of $T 6$ and S6. Male (E-M): E - lateral view; F - frontal view of head; $G$ - lateral view of head and mesosoma (for genal excavation and hypostomal concavity); $\mathrm{H}$ - dorsal view of T5-T6; I - oblique view of S4 (for both apical margin and apical rim); J - S5; $\mathrm{K}-\mathrm{S} 6$; L - S8; M - genitalia. Scale bar = $1.5 \mathrm{~mm}(\mathrm{~A}-\mathrm{I}) ; 1 \mathrm{~mm}(\mathrm{~J}-\mathrm{M})$. 
Structure. F1 shorter than F2, but longer than half F2 length, subequal to pedicel in length. Ocelloccipital distance longer than ocellocular distance. Compound eye distinctly convex basally. Apical margin of clypeus simple, nearly truncate. Pronotal lamella conspicuously elevated, nearly straight, not forming distinct lobes. Mesoscutellum lacking dorso-median ridge, posterior margin not produced medially, rounded, nearly truncate; mesoscutellum dorsal and posterior surfaces separated by subcarinate, punctate edge. Axilla acute, slightly curved apically, short, detached part much shorter than non-detached part. Forecoxal apical spine-like projections short, flat, rounded apically. T1 basal concavity not carinate. T6 elongate, tapering towards apex, subacute apically, lateral carinae sharp, complete, reaching the apex, dorsal carina sharply, conspicuously elevated, separating two shallow, elliptical depressions. S5 elongate, triangular, gradually tapering towards apex. S6 triangular, gradually tapering apically, flexed downwards, lateral margins convergent towards apex, forming nearly acute angle subapically, apex subacute, ventral surface convex, not carinate medially. In some females the subapical ventral surface of S6 is carinate medially.

Redescription male. Measurements (one specimen, "25 E of Durham Downs", ANIC). Body length: $5.73 \mathrm{~mm}$; forewing length: $4.06 \mathrm{~mm}$; head width: $1.98 \mathrm{~mm}$.

Colouration. As in female except as follows: T1 black throughout.

Pubescence. As in female except as follows: Face densely covered with appressed, long, white hairs; hypostomal concavity covered with very short, white hairs, longer hairs on anterior margins; genal excavation densely covered with appressed, plumose white hairs. Transverse fascia anteriorly on mesoscutum inconspicuous, formed by a small spot of appressed hairs medially. Gradular grooves of T5T6 conspicuously fasciate with appressed, plumose, white hairs, gradular groove of T4 not fasciate. Long, suberect, pale setae arising from punctures on $\mathrm{T} 6$.

Surface sculpture. As in female except as follows: Postgradular areas of T2-T3 indistinct, with elliptical, transverse, shining, impunctate area laterally on each side. T6 moderately densely punctate medially, punctures small, circular, sparsely punctate towards apex, punctures larger, elliptical.

Structure. Hypostomal concavity shallow, shorter than half length of compound eye. Gena deeply excavated along lower margin of eye, its length subequal to half eye length, excavation not linear, its posterior margin greatly enlarged anteriorly, excavation longer than broad, its length about $3 \times$ longer than its width. Forecoxal apical spine-like projections short, flat, rounded apically. Spine-like processes of T5 robust, separated from tergal surface apically. Basolateral processes of $\mathrm{T} 6$ long, acute, flattened laterally; dorsal processes elongate, rounded apically, slightly divergent; ventral processes acute apically, cylindrical, slightly divergent. T7 rounded apically. Apical margin and apical rim of S4 entire, in the same level, not angled in lateral view. Apical margin of S5 entire, slightly flattened medially. Apical rim of S5 entire. Gradulus of S5 angulate



Fig. 4. Distribution records for Coelioxys froggatti.

towards base, semicircular. S6 membranous, gradulus indistinct, pregradular areas narrow, elongate, weakly sclerotized on inner margins, strongly sclerotized along outer margins, narrowly acute at base, apical half of pregradular area densely setose, less setose on outer margins, postgradular area transparent medially, broad at base, basal membranous lip rounded. S7 obsolescent, represented by two small sclerites. S8 base elongate, rounded apically, its apex entire, rounded. Gonocoxa compressed laterally, with some long setae apically, longer than penis valve in length.

Comments. The name $C$. victoriae was synonymized with $C$. froggatti because both female holotypes are indistinguishable.

Floral records. According to data labels some specimens were collected on flowers of Ptilotus sp. (Amaranthaceae), Jacksonia sp., Psoralea patens Lindl. (Fabaceae), Goodenia caerulea R. Br., Scaevola glandulifera DC. (Goodeniaceae), Angophora floribunda (Sm.) Sweet, Eucalyptus largiflorens F. Muell., Melaleuca sp. (Myrtaceae), Morgania sp. (Plantaginaceae), Comesperma sp. (Polygalaceae) and Atalaya hemiglauca F. Muell. ex Benth. (Sapindaceae).

\section{Host records. None.}

Geographical distribution. Australia (New South Wales, Queensland, South Australia, Victoria, Western Australia) (Fig. 4).

Type material examined. Holotype. Coelioxys froggatti. AUSTRALIA. Victoria. 1ㅇ (USNM), "Victoria, Melbourne, W W F, 1904”, “57”, “TypeNo, 55870, USNM", “Coelioxys froggatti, Ckll. TYPE.", "USNM ENT, 00536881”. Holotype. Coelioxys victoriae. AUSTRALIA. Victoria. 1 q (ANIC), "TYPE", "GUNBOWER, V., 3/3/33", “Coelioxys victoriae ?, v. rufa. RAYM.”.

Additional material examined. AUSTRALIA. New South Wales. 1 우 (AMS), Clarence, Blue Mtns; 1 ( of Clarence, Blue Mts; 1 ( (AMS), MT Boyce, Blue Mountains; $1 \widehat{\jmath}$ (AMS), Pooncarle; $1 \hat{\jmath}$ (AMS), $100 \mathrm{~km}$ E. of Wilcannia; $1 \hat{\sigma}$ (QM), $53 \mathrm{~km} \mathrm{~W}$. of Cobar; 1ठ (QM), $34 \mathrm{~km} \mathrm{S.W.} \mathrm{of} \mathrm{Bourke;}$ 1 우소 (MVMA), Canowindra. Queensland. $1 \hat{\jmath}$ (ANIC), $25 \mathrm{E}$. 
of Durham Downs; $192 \hat{\jmath}$ (ANIC), Edungalba; 1 우 1ð (MCZ), Cunnamulla; $2 q(\mathrm{QM})$, Yelarbon; $1 \delta^{\Uparrow}(\mathrm{QM}), 38 \mathrm{~km}$ E. of Cunnamulla; 1q (QM), Quilberry Creek, $106 \mathrm{~km} \mathrm{SW}$ of Charlesville; $1{ }^{\lambda}(\mathrm{QM}), 6 \mathrm{mls}$ SW of Warwick; $1 \hat{\jmath}(\mathrm{QM}), 30 \mathrm{ml}$. N of Windorah. South Australia. 1 1 $1 \delta^{\hat{\jmath}}$ (ANIC), Orroroo; $1 \sigma^{\lambda}$ (WAM), $10 \mathrm{~km}$ ENE of Stuart Ck. Hs; $3 \hat{\jmath}$ (SAM), Orroroo. Victoria. $3 \circ$ (ANIC),

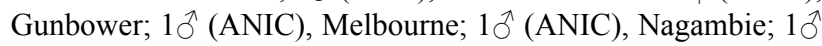
(ANIC), Gippsland; 19 (MVMA), L. Kangaroo. Western Australia. 1우 (ANIC), Fremantle; 1 ㅇ (ANIC), January Swan River; 1 으 (QM), King River, $11 \mathrm{~km}$ NNE of Albany; 1 우 (QM), Serpentine Dam, Reserve via Jarrahdale; $2 \circ$ (MVMA). Mt. Yokine; $1 ð$ (MVMA), Bushmead; $2+1 \delta$ (WAM), Midland; $1 ð$ (WAM), Yallingup; $1 \delta$ (WAM), Narrogin; 1 우 (WAM), Swanbourne; 1 우 (WAM), Hillarys, Perth; $1 \hat{\jmath}$ (WAM), Blue Rock ca. $4.5 \mathrm{~km}$ E. of Jarrahdale; 19 (WAM), Cranbrook; $191 \delta$ (WAM), Gooseberry Hill, $19 \mathrm{~km}$ E. of Perth; 1 + (WAM), Thomsons Lake, $23 \mathrm{~km} \mathrm{~S}$. of Perth; 19 (WAM), 1-13 km NE of Wanneroo; 19 (WAM), Point Malcolm; 3 ( (WAM), Kings Park, Perth; 1 (WAM), 70 mi. S of Onslow.

\section{Coelioxys reginae Cockerell, 1905}

(Figs 5A-N, 6)

Diagnosis. This is the only Australian species in which the S6 of the female is conspicuously notched subapically and the S4 apical margin in the male is angled to the apical rim. In spite of the resemblance of $C$. reginae to $C$. froggatti and $C$. tasmaniana the first can be differentiated from the other two by the apical fasciae on terga interrupted medially, the apical fasciae on sterna weakened medially, the forewing weakly infuscate on the apical half and the mesoscutal sculpturing never areolate. In females of $C$. reginae the compound eye is not convex towards the base (close to mandible; seen in lateral view) as in both $C$. froggatti and C. tasmaniana and S6 is conspicuously notched subapically contrasting to the angled lateral margins subapically found in the other two species. In males the T6 dorsal processes are short, broad, broadly rounded apically (elongate and narrow in C. froggatti and C. tasmaniana) and the S4 apical margin is elevated, angled to apical rim in lateral view (both surfaces not angled in the other two species).

Redescription, female. Measurements (one specimen, Bundaberg, Qld., ANIC). Body length: $6.88 \mathrm{~mm}$; forewing length: $5.10 \mathrm{~mm}$; head width: $2.29 \mathrm{~mm}$.

Colouration. Black except as follows: Antenna, mandible, labrum, tegula, legs, sterna dark brown to blackish; wings weakly infuscate on apical half; veins brown.

Pubescence. White, appressed/subappressed on: Paraocular area, supraclypeal area (slightly sparse medially), clypeus (sparse medially), dense fringe on apical margin of clypeus, gena, mandible basally, lateral margins of mesoscutum, mesopleuron, mesepisternum, ventral surface of mesepisternum, legs, apical fascia on sterna (slightly diluted medially). Ocular hairs whitish and long (about $0.10 \mathrm{~mm}$ ). Scattered, suberect, slender, whitish setae on paraocular area and supraclypeal area. Upper paraocular area hairs long, yellowish distinct from those of adjacent regions, oriented mesad, apices of some from each side almost meeting medially. Scattered, slender, suberect, long, pale setae on dorsal surface of mandible. Slender, suberect, pale setae arising from punctures on vertex and mesos- cutum. Thick, yellow setae on tarsi. Appressed, elongate, plumose, white hairs on a small spot medially on anterior margin of mesoscutum, two slender, transverse sublateral spots between mesoscutellum and mesoscutum, laterally on subaxilla, lateral bands on T1, on apical fasciae of T1T5 (interrupted medially) and elliptical, dense tufts on lateral margins of T6. Erect, long, thin pale hairs on posterior surface of mesoscutellum and metanotum. Postgradular area of S6 except subapical area covered with minute, very short, suberect pale setae.

Surface sculpture. Ocellar area coarsely and densely punctate; vertex moderately densely punctate; mesoscutum coarsely and densely punctate, punctures separated by at most one third their diameters except less dense medially where interspaces are at most two thirds the puncture diameter or larger than puncture diameter; mesoscutellum coarsely and densely punctate to areolate; axilla coarsely and densely punctate; T1 moderately densely punctate, interspaces among punctures shining, larger than puncture diameter; pregradular areas of T2-T5 moderately densely punctate, interspaces shining, smooth; postgradular areas of T2-T5 shining, sparsely punctate laterally, T6 minutely and moderately densely punctate basally, punctures very small, coarsely punctate apically, some punctures fused one another; S1 punctate; postgradular areas of S2-S4 moderately densely punctate basally, sparsely punctate towards apex, postgradular area of S5 dull, sparsely punctate basally, densely punctate apically, postgradular area of S6 dull, moderately densely punctate basally, imbricate to punctate apically.

Structure. F1 shorter than F2, but longer than half F2 length, subequal to pedicel in length. Ocelloccipital distance longer than ocellocular distance. Compound eye not convex basally. Apical margin of clypeus simple, nearly truncate. Pronotal lamella conspicuously elevated, nearly straight, not forming distinct lobes. Mesoscutellum lacking dorso-median ridge, posterior margin not produced medially, rounded, nearly truncate; mesoscutellum dorsal and posterior surfaces separated by subcarinate, punctate edge. Axilla acute, not curved apically, nearly parallel one another, short, detached part much shorter than non-detached part. Forecoxal apical spine-like projections short, flat, subacute apically. T1 basal concavity not carinate. T6 elongate, tapering towards apex, subacute apically, lateral carinae sharp, complete, reaching the apex, dorsal carina sharply, conspicuously elevated, separating two shallow, elliptical depressions. S5 elongate, triangular, gradually tapering towards apex. S6 triangular, gradually tapering apically, flexed downwards, lateral margins convergent towards apex, forming two conspicuous, triangular notches, apex subacute, ventral surface convex, carinate medially. The carina on ventral surface of S6 varies from sharp to obsolescent.

Redescription, male. Measurements (one specimen, Yeppoon, Qld., ANIC). Body length: $7.29 \mathrm{~mm}$; forewing length: $4.79 \mathrm{~mm}$; head width: $2.50 \mathrm{~mm}$.

Colouration. As in female. 


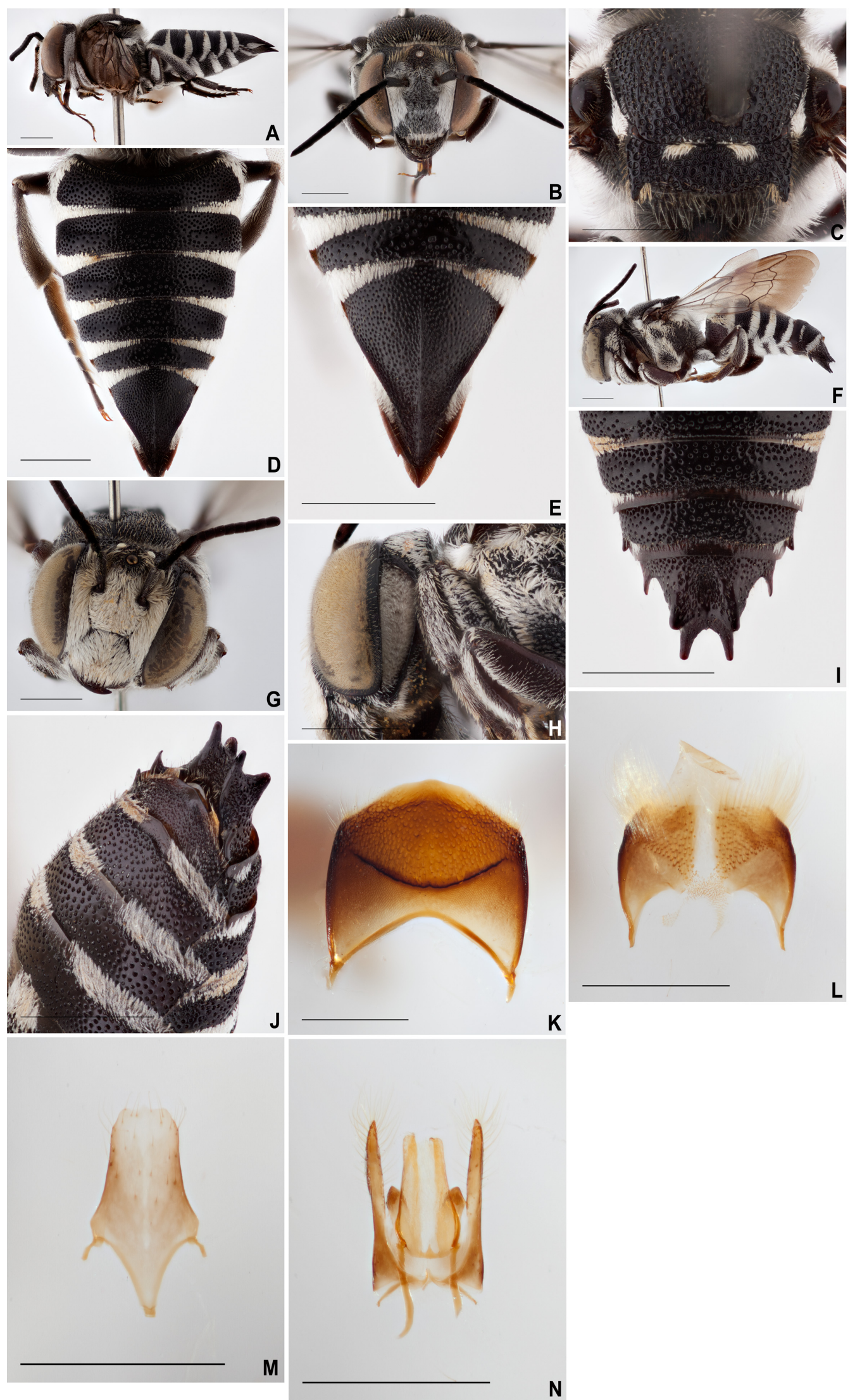

Fig. 5. Coelioxys reginae. Female (A-E): A - lateral view; B - frontal view of head; $C$ - dorsal view of mesoscutum and mesoscutellum; $\mathrm{D}$ - dorsal view of metasoma (for apical fasciae on terga); $\mathrm{E}$ - dorsal view of $\mathrm{T} 6$ and $\mathrm{S} 6$. Male (F-N): $\mathrm{F}-$ lateral view; $\mathrm{G}-$ frontal view of head; $\mathrm{H}$ - lateral view of head and mesosoma (for genal excavation and hypostomal concavity); I - dorsal view of T5-T6; J - oblique view of S4 (for both apical margin and apical rim); K - S5; L - S6; M - S8; N - genitalia. Scale bar = $1.5 \mathrm{~mm}(\mathrm{~A}-\mathrm{J}) ; 1 \mathrm{~mm}(\mathrm{~K}-\mathrm{N})$. 
Pubescence. As in female except as follows: Face densely covered with appressed, long, white hairs; hypostomal concavity covered with very short, white hairs, longer hairs on anterior margin; genal excavation densely covered with appressed, plumose white hairs. Gradular grooves of T5T6 conspicuously fasciate with appressed, plumose, white hairs, gradular groove of T4 not fasciate. Long, suberect, pale setae arising from punctures on T6.

Surface sculpture. As in female except as follows: Postgradular areas of T2 indistinct, with elliptical, transverse, shining area with few sparse punctures laterally on each side, on T3 nearly impunctate. T6 moderately densely punctate medially, punctures small, circular, sparsely punctate towards apex, punctures larger, elliptical.

Structure. Hypostomal concavity shallow, shorter than half length of compound eye. Gena deeply excavated along lower margin of eye, its length subequal to half eye length, excavation not linear, its posterior margin greatly enlarged anteriorly, excavation longer than broad, its length about $3.5 \times$ longer than its width. Forecoxal apical spine-like projections long, flat, subacute apically. Spine-like processes of T5 robust, separated from tergal surface apically. Basolateral processes of T6 long, acute, flattened laterally, divergent; dorsal processes short, broad, rounded apically, divergent; ventral processes acute apically, cylindrical, slightly divergent. In some males the T6 dorsal processes can be slightly slanting. T7 slightly tapering towards apex, rounded apically. Apical margin and apical rim of S4 entire, apical margin elevated, forming an angle to apical rim. Apical margin of S5 entire, slightly flattened medially. Apical rim of S5 entire. Gradulus of S5 semicircular. S6 membranous, gradulus indistinct, pregradular areas narrow, elongate, weakly sclerotized on inner margins, strongly sclerotized along outer margins, narrowly acute at base, apical half of pregradular area copiously and densely setose, less setose on outer margins, postgradular area transparent medially, broad at base, basal membranous lip rounded. S7 obsolescent, represented by two small sclerites. S8 base elongate, subacute apically, its apex entire, rounded. Gonocoxa compressed laterally, with some long setae apically, longer than penis valve in length.

Comments. Both $C$. reginae and $C$. albolineata have similar distribution patterns throughout northern region of Northern Territory and along northern Queensland coast. Nonetheless, the former is also found in southern Queensland inland and New South Wales but is absent in Western Australia in contrast to the range of $C$. albolineata.

Floral records. Some specimens were collected on flowers of Cajanus cajan (L.) Huth, Daviesia sp. (Fabaceae), Eucalyptus foelscheana F. Muell. (Myrtaceae), Persoonia sp. (Proteaceae) and Atalaya hemiglauca F. Muell. ex Benth. (Sapindaceae).

Host records. None.

Geographical distribution. Australia (New South Wales, Northern Territory, Queensland) Papua New Guinea (Central, East New Britain, Eastern Highlands, Morobe) (Fig. 6).

Type material examined. Holotype. Coelioxys reginae. AUSTRALIA. Queensland. 1ㅇ (BMNH). "Mackay", “320", "Mackay, Queensland., G. Turner., 1892-16.”, “Coelioxys reginae, Ckll

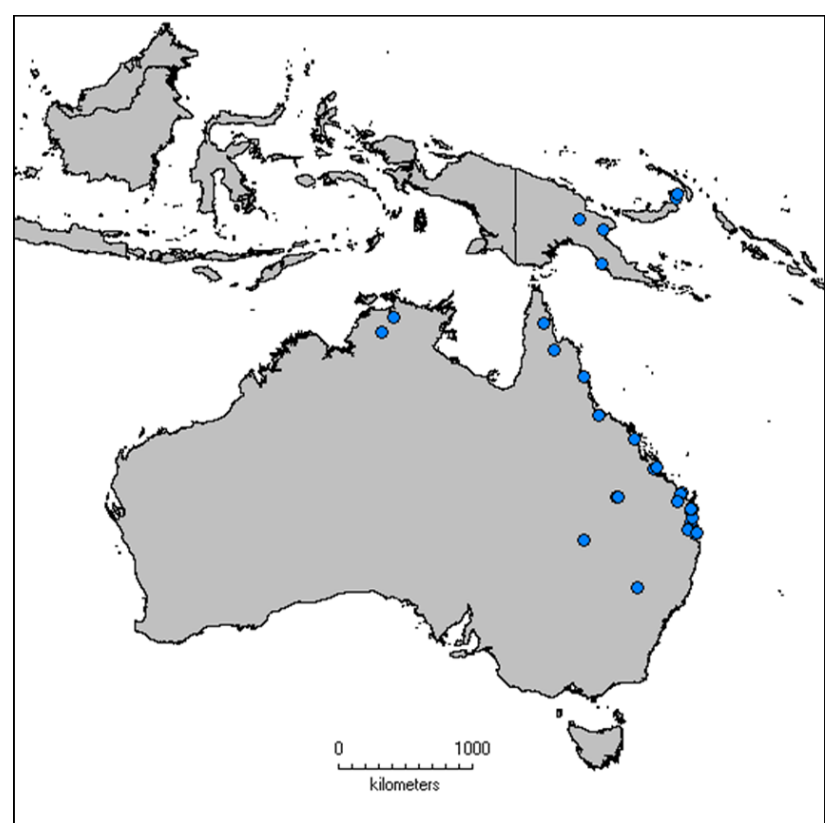

Fig. 6. Distribution records for Coelioxys reginae.

TYPE”, “Тype”, “B.M.TYPE, HYM., 17.B.29.”, “BMNH(E), \#970538',

Additional material examined. AUSTRALIA. New South Wales. $1 \delta^{\circ}(\mathrm{QM}), 50 \mathrm{~km} \mathrm{~W}$. of Coonabarabran. Northern Terri-

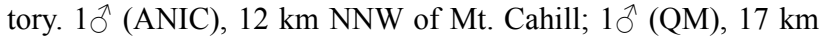
N. of Pine Creek. Queensland. 19 (ANIC), Electra $25 \mathrm{~km} \mathrm{SW}$ of Bundaberg; 1 ㅇ (ANIC), $4 \mathrm{~km} \mathrm{NW} \mathrm{Bundaberg;} 1$ 을 (ANIC), Bundaberg; $1 \delta^{\Uparrow}$ (ANIC), Yeppoon; $1 \delta$ (ANIC), Gooburrum Shire nr. Bundaberg; $1 \delta$ (MCZ), Cunnamulla; 1 으 (PCYU), Brisbane Forest Park; $1 \delta$ (WAM), 2 mls. N. Peregian; 1 ( $(\mathrm{QM})$, Eighteen Mile Swamp, Stradbroke Is.; 19 (QM), Stradbroke Island; 1 ㅇ (QM), Carnarvon Nat. Park, Mt. Moffatt Section; 1 ( $(\mathrm{QM})$, Mt. Moffatt Nat. Pk, 3 km SE Park Headquarters; 19 (QM), Mt Woowoonga, 1.4 km SW.; 19 (QM), Stony Ck, via Samford; 1 q (QM), Johannsens Cave; $1 \precsim(\mathrm{QM})$, Ross River Reservoir, $10 \mathrm{~km}$ $\mathrm{S}$ Townsville; $1+1{ }^{\Uparrow}(\mathrm{QM})$, Yeppoon; $19(\mathrm{QM})$, Redland Bay; 1 으 (QM), Cooloola state, Forest near tin, Can Bay; 1우 (QM), Morehead River; $1 \widehat{\delta}(\mathrm{QM}), 3 \mathrm{~km}$ SW Fox Ck; 1 + $1 \hat{\delta}$ (MVMA), Barron Waters; $1 \delta$ (WAM), Cooloola State, Forest near Tin, Can Bay; $1 \delta$ (WAM), Beerwah. PAPUA NEW GUINEA. Central. $1 \delta$ (BPBM), Laloki, Papua. East New Britain. $2 \uparrow$ (BPBM), New Britain, Gazelle Pen., Bainings: St., Paul's 350 m.; 29 (BPBM), New Britain, Vunabakan, 180 m., 10 km E. of Keravat. Eastern Highlands. $1 \widehat{\delta}$ (BPBM), New Guinea: Papua, Goroka, $1530 \mathrm{~m}$. Morobe. $1 \delta$ (BPBM), New Guinea: NE Nasawapum, 30 km., NW of Lae.

\section{Coelioxys tasmaniana sp. $\mathbf{n}$.}

(Figs 7A-J, 8)

ZooBank taxon LSID:

DAE209AB-A8EC-429B-9239-BC3809D51126

Diagnosis. Coelioxys tasmaniana is very similar to $C$. froggatti. They share some distinctive characters not found in the other Australian species as in females the compound eye is convex basally and the lateral margins of S6 angled to subangled (but inconspicuously notched in the female holotype of $C$. tasmaniana). Also in males the dorsal processes of T6 are elongate and the apical margin of S4 is not elevated. These two species can be distinguished by 




Fig. 7. Coelioxys tasmaniana. Female (A-E): A - lateral view; $B$ - frontal view of head; $C$ - dorsal view of mesoscutum and mesoscutellum; D - dorsal view of T1 (for basal fascia); E - dorsal view of T6 and S6. Male (F-J): F - lateral view; $\mathrm{G}$ - frontal view of head; $\mathrm{H}$ - lateral view of head (for genal excavation and hypostomal concavity); I - dorsal view of T5-T6; J - oblique view of S4 (for both apical margin and apical rim). Scale bar $=1.5 \mathrm{~mm}$.

the suberect, long, thin hairs on the face, mesoscutum and mesepisternum observed in C. tasmaniana that contrasts to the appressed, plumose hairs of $C$. froggatti. Additionally, the posterior surface of the mesoscutellum and the metanotum medially in $C$. froggatti are covered with scale-like, appressed hairs whereas in C. tasmaniana both are covered with elongate, suberect hairs.
Description, female. Measurements (holotype). Body length: $6.72 \mathrm{~mm}$; forewing length: $3.76 \mathrm{~mm}$; head width: $1.88 \mathrm{~mm}$.

Colouration. Black except as follows: Antenna, labrum, tegula, legs, sterna dark brown to black; wings subhyaline; veins brownish. 
Pubescence. White, suberect on: Paraocular area; supraclypeal area; clypeus, fringe on apical margin of clypeus; gena; mandible basally; subaxilla; two slender, small, sublateral spots between mesoscutum and mesoscutellum; metanotum; propodeum; basolateral bands on T1. White, subappressed on ventral surface of mesepisternum, legs, apical fascia on sterna (interrupted medially). Ocular hairs white and long (about $0.12 \mathrm{~mm}$ ). Upper paraocular area hairs long, whitish distinct from those of adjacent regions, oriented mesad, apices of some from each side almost meeting medially. Scattered, slender, suberect, long, pale setae on dorsal surface of mandible. Slender, suberect, whitish setae arising from punctures on vertex and mesoscutum. Thick, yellow setae on tarsi. Basal concavity of T1 with a fascia composed of suberect, short, pale setae. Appressed, elongate, plumose, white hairs on lateral bands on T1, on apical fasciae of T1-T5 and elliptical, dense tufts on lateral margins of T6. Postgradular area of S6 except subapical area covered with sparse, minute, very short, subappressed pale setae.

Surface sculpture. Ocellar area coarsely and densely punctate; vertex coarsely and densely punctate but an impunctate, shining area laterally to lateral ocelli; mesoscutum coarsely punctate to areolate, punctures separated by at most one fifth their diameters except less dense medially where interspaces are at most two thirds the puncture diameter; mesoscutellum coarsely and densely punctate to areolate; axilla coarsely and densely punctate; T1 moderately densely punctate, interspaces among punctures shining, larger than puncture diameter; pregradular areas of T2-T5 moderately densely punctate, interspaces shining, smooth; postgradular areas of T2-T5 shining, sparsely punctate laterally, T6 minutely and moderately densely punctate basally, punctures very small, coarsely punctate apically, some punctures fused one another; S1 punctate; postgradular areas of S2-S4 moderately densely punctate basally, sparsely punctate towards apex, postgradular area of S5 smooth, sparsely punctate basally, densely punctate

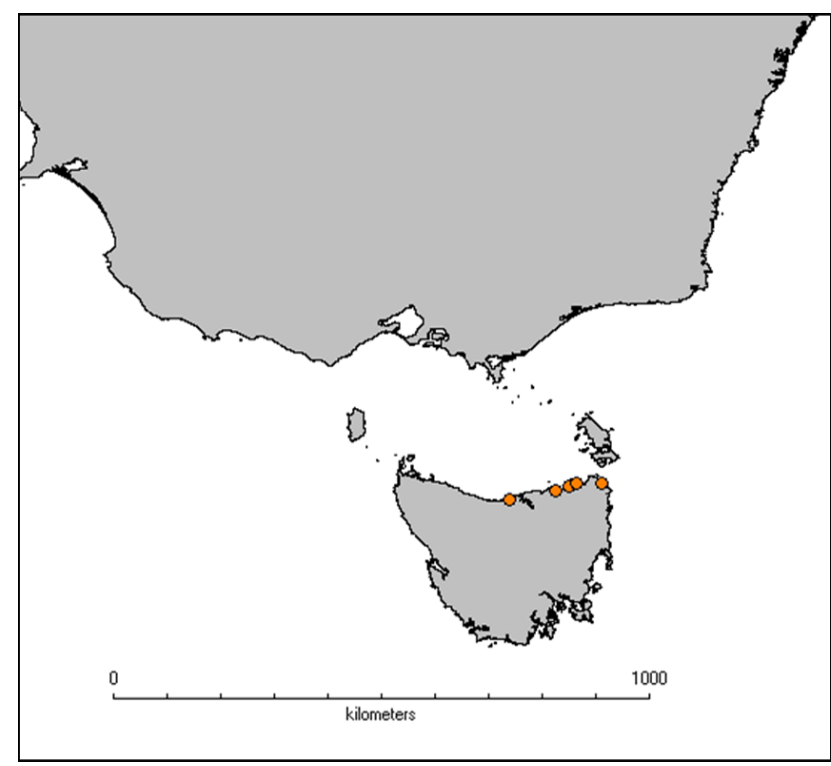

Fig. 8. Distribution records for Coelioxys tasmaniana. apically, postgradular area of S6 dull, moderately densely punctate basally, imbricate to punctate apically.

Structure. F1 shorter than F2, but longer than half F2 length, subequal to pedicel in length. Ocelloccipital distance longer than ocellocular distance. Compound eye distinctly convex basally. Apical margin of clypeus simple, nearly truncate. Pronotal lamella conspicuously elevated, nearly straight, not forming distinct lobes. Mesoscutellum lacking dorso-median ridge, posterior margin not produced medially, rounded, nearly truncate, slightly depressed; mesoscutellum dorsal and posterior surfaces separated by subcarinate, punctate edge. Axilla acute, not curved apically, detached part slightly shorter than non-detached part. Forecoxal apical spine-like projections short, flat, acute apically. T1 basal concavity not carinate. T6 elongate, tapering towards apex, subacute apically, lateral carinae sharp, complete, reaching the apex, dorsal carina sharply, conspicuously elevated, separating two shallow, elliptical depressions. S5 elongate, triangular, gradually tapering towards apex. S6 triangular, gradually tapering apically, flexed downwards, lateral margins convergent towards apex, forming two discrete, subtriangular notches subapically in the holotype, in remaining females not notched but subangled to angled subapically, apex subacute, ventral surface convex, carinate medially. The ventral carina on S6 can be rounded, sometimes nearly absent, not conspicuously elevated.

Description, male. Measurements (one paratype, Asbestos Range Nat. Pk, Tas., QM). Body length: 6.09 mm; forewing length: $3.20 \mathrm{~mm}$; head width: $1.89 \mathrm{~mm}$.

Colouration. As in female.

Pubescence. As in female except as follows: Hairs on face pale; hypostomal concavity covered with sparse, long, whitish hairs curved apically; genal excavation sparsely covered with suberect, long whitish hairs. Gradular grooves of T6 conspicuously fasciate with appressed, plumose, long, white hairs, T4-T5 not fasciate. Long, suberect, whitish setae arising from punctures on T6.

Surface sculpture. As in female except as follows: Postgradular areas of T2-T3 indistinct, with a very few small punctures laterally on each side. T6 moderately densely punctate medially, punctures small, circular, sparsely punctate towards apex, punctures larger, elliptical.

Structure. Hypostomal concavity shallow, shorter than half length of compound eye. Gena deeply excavated along lower margin of eye, its length longer than half eye length, excavation not linear, its posterior margin greatly enlarged anteriorly, excavation longer than broad, its length about $3 \times$ longer than its width. Forecoxal apical spine-like projections short, flat, acute apically. Spine-like processes of T5 robust, separated from tergal surface apically. Basolateral processes of T6 long, rounded apically, flattened laterally; dorsal processes elongate, rounded apically, slightly divergent; ventral processes acute apically, cylindrical, slightly divergent. T7 rounded apically. Apical margin and apical rim of S4 entire, in the same level, not angled in lateral view. Apical margin of S5 entire, slightly flattened medially. Apical rim of S5 entire. 
Comments. This is the only species recorded from Tasmania and its distribution is restricted to this island. As only two males were available the terminalia were not dissected.

Etymology. The epithet "tasmaniana" refers to distributional range of this species that is restricted to that island.

\section{Floral records. None.}

Host records. None.

Geographical distribution. Australia (Tasmania) (Fig. 8).

Type material. Holotype. AUSTRALIA. Tasmania. 19 (QM T232438), sand dunes behind Bakers, Bch Asbestos Range Nat. Pk, Tas $41^{\circ} 09^{\prime} \mathrm{S}, 146^{\circ} 35^{\prime} \mathrm{E}$, 14 Jan 1992, G. and A. Daniels. Paratypes. AUSTRALIA. Tasmania. QM T232439-T232444: $1 \delta^{\lambda}$ (QM), Asbestos Range Nat. Pk, Tas $41^{\circ} 09^{\prime} \mathrm{S}, 146^{\circ} 35^{\prime} \mathrm{E}$, 14 Jan 1992, G. and A. Daniels; 3 (QM), Granite Point Reserve, Bridport, Tas, $40^{\circ} 59^{\prime} \mathrm{S}, 147^{\circ} 23^{\prime} \mathrm{E}, 17$ Jan 1992, G. and A. Daniels; 1 ㅇ (QM), horse yards area, Mt. William Nat. Pk Tas, $40^{\circ} 52^{\prime} \mathrm{S}$, $148^{\circ} 10^{\prime} \mathrm{E}, 20$ Jan 1992, G. and A. Daniels; 2 (Q (QM), $2 \mathrm{~km} \mathrm{~S}$ Tomahawk, Tas, $40^{\circ} 52^{\prime} \mathrm{S}, 147^{\circ} 45^{\prime} \mathrm{E}, 2$ Feb 1988, G. and A. Daniels, in sand dunes. $1 \delta$ (MVMA), Blackmans Lagoon, NE Tas. 11. Nov., 1972. A. Neboiss. HYM-32817. MUS. VIC., ENTO 2014-IIL.

\section{Coelioxys (Torridapis) julia sp. $\mathbf{n}$.}

(Figs 9A-K, 10)

ZooBank Taxon LSID:

C2CBDFB8-F7A2-4F20-8C05-B67743F88BFD

Diagnosis. Among Australian Coelioxys this new species and $C$. weinlandi are the only ones with bare eyes and heavily infuscate wings. Coelioxys julia is very similar to $C$. weinlandi from which it can be differentiated by the black pubescence on the vertexal and occipital areas; mesoscutum sparsely punctate, with polished interspaces between punctures; lack of a dorsal carina medially on posterior margin of mesoscutum and white pubescence on ventral surface of mesepisternum. Females of $C$. julia can be distinguished by the apical margin of clypeus simple; lack of sparse appressed hairs sublaterally on S2-S4 and evanescent lateral carinae on T6 subapically. Males can be separated from those of $C$. weinlandi by the inconspicuously elevated processes of S4 apical margin; long, acute teeth basally on T6 and lack of apicolateral white bands on the metasomal terga.

Description, female. Measurements (holotype). Body length: $7.84 \mathrm{~mm}$; forewing length: $4.92 \mathrm{~mm}$; head width: $1.95 \mathrm{~mm}$.

Colouration. Black except as follows: Antenna dark brown, legs blackish; tarsal claws light brown; wings heavily infuscate with dark blue to violet reflections; veins dark brown.

Pubescence. White, subappressed/suberect on: Paraocular area; supraclypeal area; basal half of clypeus; gena; two sublateral, inconspicuous lines on anterior margin of mesoscutum; pronotal lobes posteriorly; ventral surface of mesepisternum; coxae; trochanters; basitarsi; lateral tiny bands apically on T1-T5; apical fasciae on T1-T5 inconspicuous, diluted medially; lateral margins of T6; apical fasciae on S1-S4. Black, suberect on vertex posteriorly, occipital area, pronotum, lateral surface of mesepisternum, mesopleuron, mesoscutellum, axilla, propodeum, sparsely on tibiae and femurs, sparse hairs on basal concavity of $\mathrm{T} 1$, sparsely on basolateral bands on T1. Apical half of clypeus covered with brown, subappressed hairs. Scattered, erect, brownish hairs basally on labrum. Scattered, suberect, slender, whitish setae on paraocular area and clypeus and blackish setae on supraclypeal area. Upper paraocular area hairs long, blackish, distinct from those of adjacent regions, oriented mesad, apices of some from each side almost meeting medially. Slender, subappressed, short, pale setae and scattered, long, thin, brownish setae on dorsal surface of mandible. Thick, brownish setae on tarsi. Lateral margins of S6 subapically in dorsal view with an inconspicuous fringe of short, dark brown hairs with some scattered, short, slender, suberect, blackish setae apically.

Surface sculpture. Ocellar area densely punctate; vertex moderately punctate, large, elliptical punctures mixed with small punctures, interspaces between punctures polished and larger than the smaller puncture diameter; mesoscutum moderately punctate, larger, elliptical punctures anteriorly mixed with smaller, circular punctures throughout, interspaces between punctures smooth, polished and larger than smaller puncture diameter; mesepisternum and mesopleuron moderately densely punctate; mesoscutellum coarsely and densely punctate, interspaces between punctures polished and larger than puncture diameter; axilla coarsely and densely punctate, interspaces between punctures dull and shorter than puncture diameter; T1 moderately densely punctate, interspaces among punctures shining, larger than puncture diameter; pregradular and postgradular areas of T2-T5 shining, smooth, sparsely punctate medially, T6 minutely and densely punctate basally, interspaces between punctures dull, punctures very small, rugose apically; S1 sparsely punctate; postgradular areas of S2-S4 sparsely punctate, with sparse larger punctures mixed with minute punctures throughout; postgradular area of S5 dull, sparsely punctate basally, almost impunctate towards apex, postgradular area of S6 dull.

Structure. F1 subequal to half-length of F2 and shorter than pedicel. Mid ocellus surrounded anteriorly by a sharp, elevated carina that extends till interalveolar area. Ocelloccipital distance subequal to ocellocular distance. Compound eye not convex basally. Apical margin of clypeus simple, nearly truncate, not produced medially. Pronotal lamella elevated and nearly straight. Posterior half of mesoscutum lacking sharp, dorsal carina. Mesoscutellum with inconspicuous dorso-median carina basally and posterior margin angulate; mesoscutellum dorsal and posterior surfaces separated by distinct subcarinate edge. Axilla long, acute, curved apically. Metanotum expanded basally, forming a deeply sulcate area. Forecoxal apical spine-like projections short, triangular. T1 basal concavity not carinate. T6 greatly elongate, more than $2 \times$ longer than broad, gradually tapering towards apex, slightly upwardly oriented apically, lacking lateral sulcus, dorsal carina very discrete, present only subapically, lateral carinae very discrete, stronger apically and evanescent subapically, meet- 

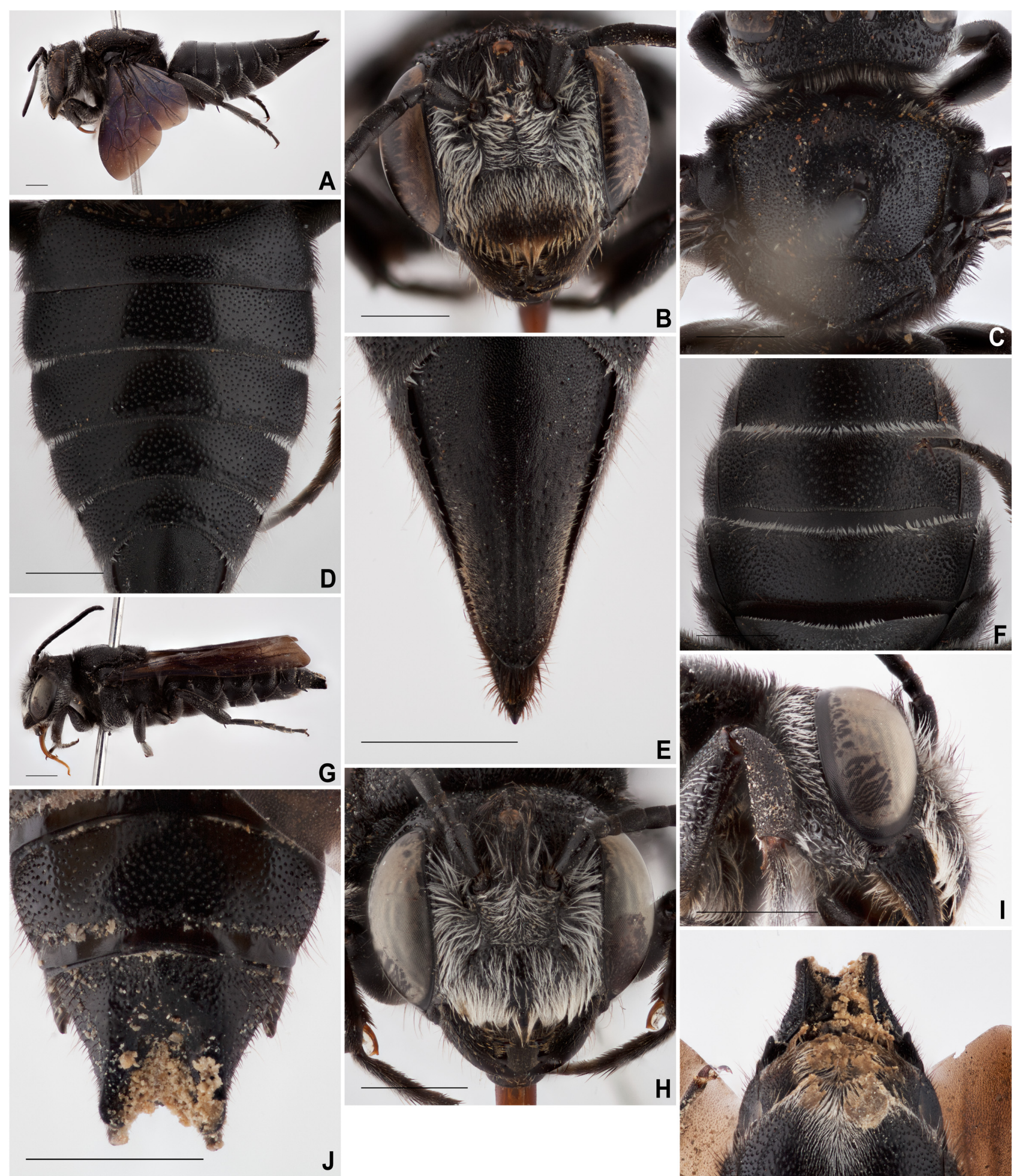

E

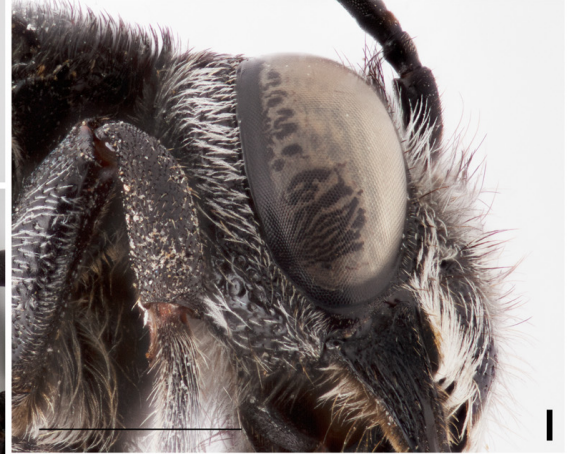

J

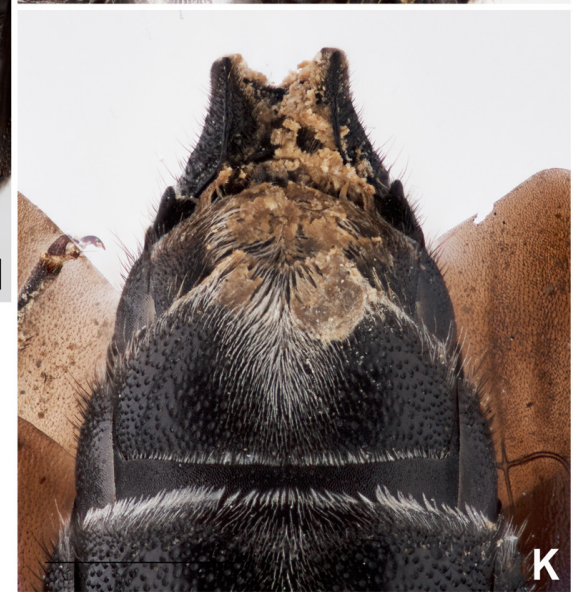

Fig. 9. Coelioxys julia. Female (A-F): A - lateral view; B - frontal view of head; C - dorsal view of mesoscutum and mesoscutellum; D dorsal view of metasoma (for apical fasciae on terga); E - dorsal view of T6 and S6; F - ventral view of S2-S4. Male (G-K): G - lateral view; $\mathrm{H}$ - frontal view of head; I - lateral view of head (for gena and hypostomal area); J - dorsal view of T6; K - ventral view of S4 (for apical margin). Scale bar $=1.5 \mathrm{~mm}$.

ing dorsal carina apically, forming a short U-shaped carina, apex subacute with an obsolescent, rounded spine medially, upwardly oriented medially. S5 greatly elongate, more than $1.5 \times$ longer than broad, triangular, gradually tapering towards apex. S6 greatly elongate, more than $2 \times$ longer than broad, folded, slightly flexed downwards, gradually 
tapering towards, apex acute, lacking notches, ventral surface not carinate medially.

Description, male. Measurements (paratype, QM). Body length: $6.61 \mathrm{~mm}$; forewing length: $3.98 \mathrm{~mm}$; head width: $1.88 \mathrm{~mm}$.

Colouration. As in female.

Pubescence. As in female except as follows: Clypeus fully covered with white subappressed hairs, more sparse medially. White, appressed hairs on half apex of S4-S5 medially. Apical margins of terga laterally lacking bands of appressed white hairs. Postgradular grooves of T2-T6 not fasciate.

Surface sculpture. As in female except as follows: Postgradular areas of T2-T3 unmodified, lacking fovea or punctate areas sublaterally. T6 sparsely punctate, interspaces between punctures polished, smooth and larger than puncture diameter.

Structure. Ocelloccipital distance subequal to ocellocular distance. Hypostomal area lacking concavity. Forecoxal apical spine-like projections short, subacute apically, triangular. Apex of T5 lacking spine-like processes. Basolateral processes of T6 long, triangular, flat, acute apically; dorsal processes short, slanting, broadly rounded apically; ventral processes subacute apically, cylindrical. Half apex of S4 flattened medially, apex forming two inconspicuously elevated processes shorter than the distance that separates them. Half apex of S5 flattened medially, not forming processes.

Comments. Coelioxys julia is only known from southeastern Queensland and northeastern New South Wales. As only the male paratype was available for this study, the terminalia were not dissected.

Etymology. The specific epithet is a noun in apposition and is named in honour of the former Prime Minister of Australia Julia Gillard for her commitment and engagement with the environmental cause in that country.

Floral records. None.

Host records. None.

Geographical distribution. Australia (New South Wales, Queensland) (Fig. 10).

Type material. Holotype. AUSTRALIA. Queensland. 1 ( (QM T232436), QLD: $28.210^{\circ} \mathrm{S}, 153.139^{\circ} \mathrm{E}$, Lamington NP. IBISCA Qld, Plot \#IQ-500-C, rainforest, 30 Jan 2007, Morris \& Sinclair, bee \& wasp nest trap, canopy, 474 m. 25542. 25542.1. Coelioxys (Torridapis) BATHI. Paratype. AUSTRALIA. New South Wales. 1 ( (SAM), Dorrigo, W. Heron. SAMA Database, No. 32-034879. Queensland. $1 \sigma^{\top}\left(\mathrm{QM}\right.$ T232437), QLD: $28.155^{\circ} \mathrm{S}, 153.139^{\circ} \mathrm{E}$, Lamington NP. IBISCA Qld, Plot \#IQ-300-B, rainforest, 26 Mar 2007, Morris \& Sinclair, bee \& wasp nest trap, canopy, $282 \mathrm{~m}$. 25857. 25857.2. Coelioxys (Torridapis) BATHI.

\section{Coelioxys (Torridapis) weinlandi Schulz, 1904}

(Figs 11A-M, 12)

Coelioxys albiceps Friese, 1909: 269.

Diagnosis. Coelioxys weinlandi and C.julia are the only species that belong to the subgenus Torridapis recorded in Australia. Both are readily recognized by their large size, often exceeding $7.5 \mathrm{~mm}$; bare eyes; heavily infuscate wings with violet reflections and dark pubescence mainly

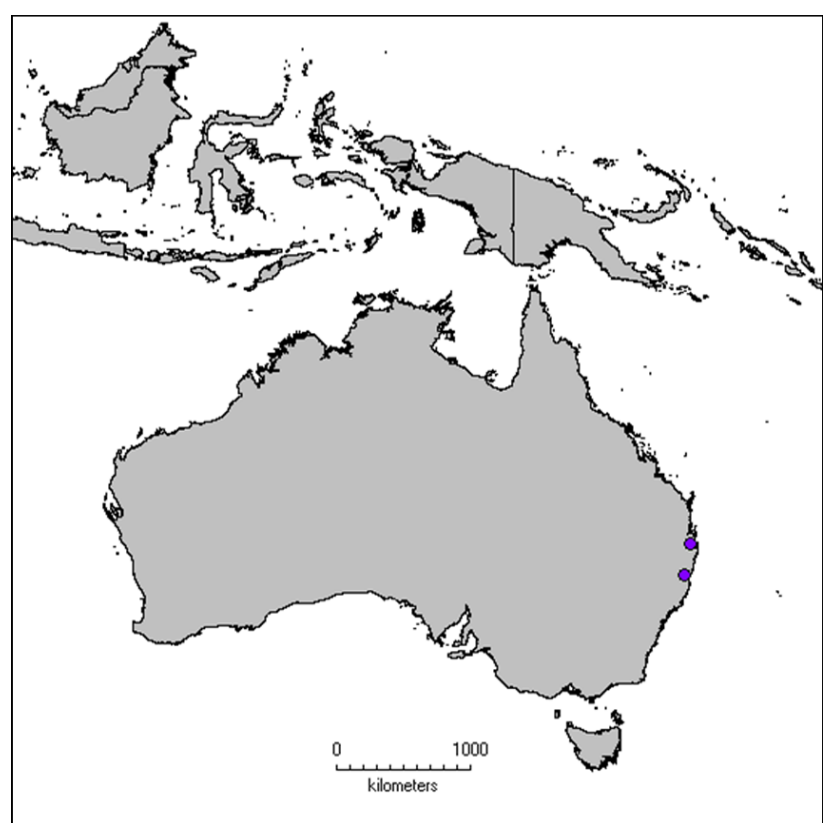

Fig. 10. Distribution records for Coelioxys julia.

on the mesosoma. In spite of their similarity, $C$. weinlandi is characterized by the dense white pubescence posteriorly on the vertex and on the occipital area; sharp dorsal carina medially on the posterior margin of the mesoscutellum; rugose, coarse sculpture of the mesoscutum, lacking polished interspaces and the dark brown pubescence on the ventral surface of the mesepisternum. In females the apical margin of the clypeus is produced medially; apical white fasciae on the metasomal terga are complete and distinct and the lateral carinae on $\mathrm{T} 6$ are not evanescent and form an elongate U-shaped carina. Males of $C$. weinlandi are differentiated from those of $C$. julia by the conspicuously elevated processes of S4 apical margin; presence of white tergal bands laterally and short lateral teeth basally on T6.

Redescription, female. Measurements (one specimen, Kevasop Village, Karkar Island, Madang Province, PNG, CAS). Body length: $11.65 \mathrm{~mm}$; forewing length: $6.15 \mathrm{~mm}$; head width: $2.51 \mathrm{~mm}$.

Colouration. Black except as follows: Antenna, legs, sterna dark brown; labrum brown; tarsal claws light brown; wings heavily infuscate with violet reflections; veins brown.

Pubescence. White, subappressed/suberect on: Paraocular area, supraclypeal area, basal half of clypeus, gena, vertex posteriorly, occipital area, two sublateral spots on anterior margin of mesoscutum, pronotal lobes posteriorly, lateral tiny bands apically on T2-T3, apical fasciae diluted medially on T4-T5, apical fasciae on S1-S4, diluted circular bands sublaterally on S2-S4. In some females the anterior region of mesoscutum is covered with a dense fascia of subappressed white hairs interrupted medially. A tiny line of subappressed white hairs may be present between the mesoscutum and mesoscutellum. Black, suberect on pronotum, mesepisternum, mesopleuron, mesoscutellum, axilla, propodeum, legs, sparse hairs on basal concavity of $\mathrm{T} 1$, basolateral bands on T1. Apical half of clypeus cov- 


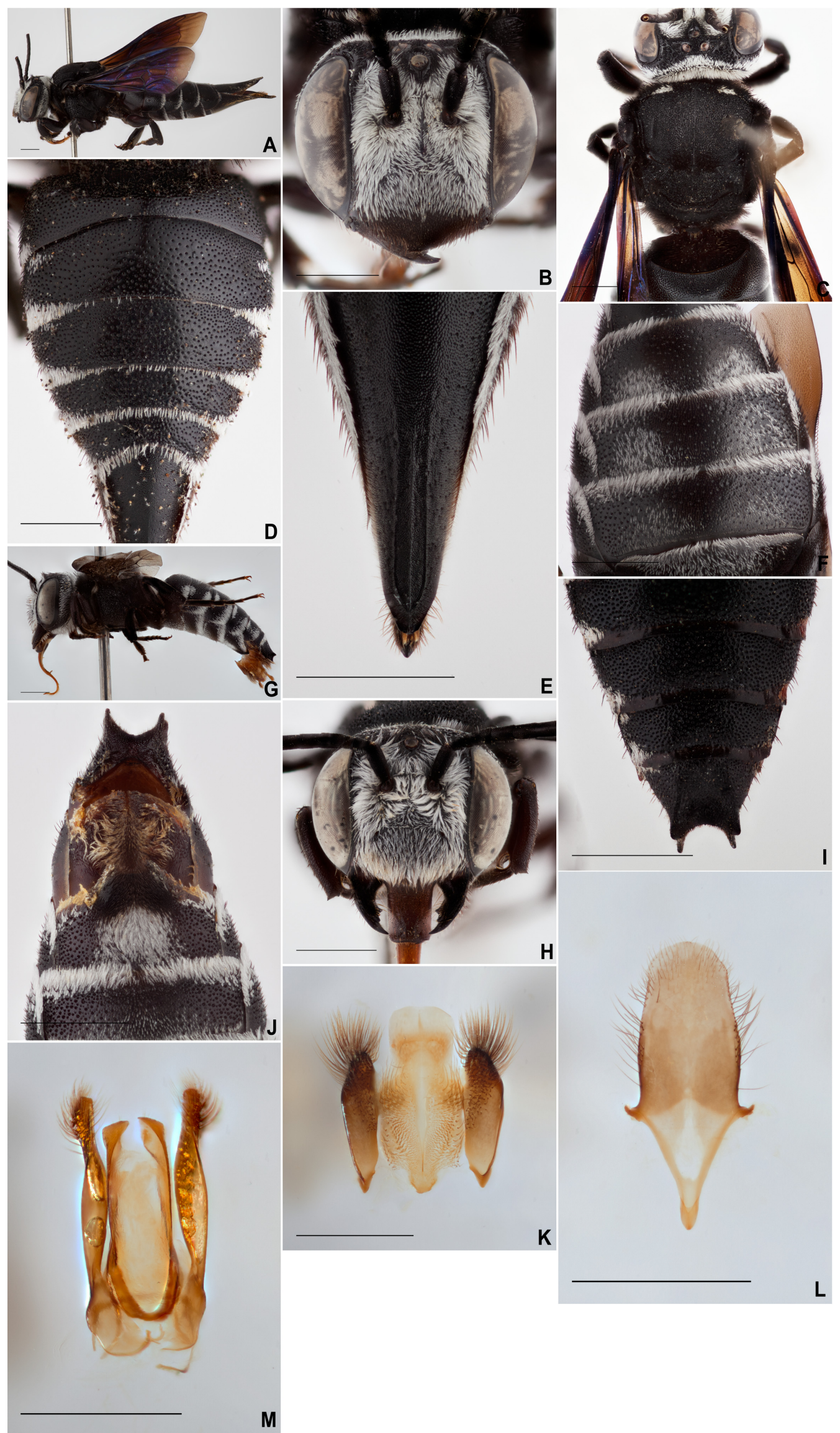

Fig. 11. Coelioxys weinlandi. Female (A-F): A - lateral view; B - frontal view of head; $C$ - dorsal view of mesoscutum and mesoscutellum; $\mathrm{D}$ - dorsal view of metasoma (for apical fasciae on terga); $\mathrm{E}$ - dorsal view of T6 and S6; F - ventral view of S2-S4. Male (G-M): G - lateral view; $\mathrm{H}$ - frontal view of head; I - dorsal view of T6; J - ventral view of S4 (for apical margin); $\mathrm{K}-\mathrm{S} 6$; $\mathrm{L}-\mathrm{S} 8$; $\mathrm{M}$ - genitalia. Scale bar = $1.5 \mathrm{~mm}(\mathrm{~A}-\mathrm{J}) ; 1 \mathrm{~mm}(\mathrm{~K}-\mathrm{M})$. 
ered with dark brown, subappressed hairs. Scattered, erect, brown hairs on labrum. Scattered, suberect, slender, blackish setae on paraocular area, supraclypeal area and clypeus. Upper paraocular area hairs long, blackish, distinct from those of adjacent regions, oriented mesad, apices of some from each side almost meeting medially. Slender, subappressed, short, brown setae and scattered, long, thin, blackish setae on dorsal surface of mandible. Thick, brownish setae on tarsi. Lateral margins of S6 subapically in dorsal view with a fringe of short, brownish hairs with some scattered, short, slender, suberect, brown setae apically.

Surface sculpture. Ocellar area densely punctate; vertex moderately densely punctate, large, elliptical punctures mixed with small punctures; mesoscutum coarsely and densely punctate, rugose, few interspaces medially, smaller than puncture diameter, small punctures intermixed with few larger, elliptical punctures; mesepisternum and mesopleuron coarsely and densely punctate; mesoscutellum rugose, coarsely and densely punctate, lacking interspaces; axilla coarsely and densely punctate, lacking interspaces; T1 moderately densely punctate, interspaces among punctures shining, larger than puncture diameter; pregradular and postgradular areas of T2-T5 shining, smooth, sparsely punctate medially, T6 minutely and densely punctate basally, interspaces between punctures dull, punctures very small, rugose apically; S1 sparsely punctate; postgradular areas of S2-S4 sparsely punctate, with sparse larger punctures mixed with minute punctures throughout; postgradular area of S5 dull, sparsely punctate basally, almost impunctate towards apex, postgradular area of S6 dull.

Structure. F1 shorter than half length F2 and shorter than pedicel. Mid ocellus surrounded by a sharp, elevated carina that extends till interalveolar area. Ocelloccipital distance longer than ocellocular distance. Compound eye not convex basally. Apical margin of clypeus produced medially, trapezoidal, its apex truncate. Pronotal lamella elevated and nearly straight. Dorsal carina medially on posterior half on mesoscutum. Mesoscutellum with dorso-median carina basally and posterior margin obtusely angulate; mesoscutellum dorsal and posterior surfaces separated by distinct subcarinate edge. Axilla long, acute, curved apically. Metanotum expanded basally, forming a deeply sulcate area. Forecoxal apical spine-like projections short, rounded. T1 basal concavity not carinate. T6 greatly elongate, more than $2 \times$ longer than broad, gradually tapering towards apex, slightly upwardly oriented apically, lacking lateral sulcus, dorsal carina very discrete, present only subapically, lateral carinae very discrete, meeting dorsal carina apically, forming an elongate U-shaped carina, apex subacute with an obsolescent, rounded spine medially, upwardly oriented medially. S5 greatly elongate, more than $1.5 \times$ longer than broad, triangular, gradually tapering towards apex. S6 greatly elongate, more than $2 \times$ longer than broad, folded, slightly flexed downwards, gradually tapering towards, apex acute, lacking notches, ventral surface not carinate medially.
Redescription, male. Measurements (one specimen, Rowes Bay, Townsville, Qld., WAM). Body length: 7.50 $\mathrm{mm}$; forewing length: $5.10 \mathrm{~mm}$; head width: $2.10 \mathrm{~mm}$.

Colouration. As in female.

Pubescence. As in female except as follows: Clypeus fully covered with white subappressed hairs, more sparse medially. White, appressed hairs forming large bands laterally on apical margins on T1-T5; on postgradular grooves of T2-T6; half base of S4 medially. Apex of pregradular area of S6 laterally and gonocoxite apically densely covered with suberect, plumose, brown hairs.

Surface sculpture. As in female except as follows: Postgradular areas of T2-T3 lacking fovea or punctate areas sublaterally. T6 moderately densely punctate.

Structure. Ocelloccipital distance subequal to ocellocular distance. Hypostomal area lacking concavity. Forecoxal apical spine-like projections short, rounded apically, flattened. Apex of T5 lacking spine-like processes. Basolateral processes of T6 short, discrete, triangular, flat; dorsal processes short, slanting, rounded apically; ventral processes subacute apically, cylindrical. T7 tapering subapically, apex rounded. Half apex of S4 deeply flattened medially, sulcate, apex forming two robust processes conspicuously elevated, slightly convergent, processes longer than the distance that separates them. Apical margin of S5 slightly emarginate, gradulus deeply angulate towards base. Gradulus of S6 indistinct but U-shaped, nearly reaching basal margin, pregradular areas narrow, elongate, weakly sclerotized on inner margins, strongly sclerotized along outer margins, narrowly acute at base, pointed at apex, postgradular area transparent medially, broad at base, basal membranous lip rounded. S7 obsolescent, represented by two small sclerites. S8 elongate basally, rounded apically. Gonocoxa strongly compressed laterally, longer than penis valve in length.

Comments. This species is known from northern Queensland in Australia and from Papua New Guinea while C. julia is only known from southeastern Queensland. Both the female syntype of $C$. albiceps and female holotype of $C$. weinland $i$ were compared and they share the same diagnostic characteristics and cannot be differentiated.

Floral records. None.

Host records. Friese (1909) mentioned that according to Biró C. weinlandi (cited as C. albiceps) is a parasite of Ctenoplectra chalybea Smith (Apidae). However, Michener (1965) emphasized this record was certainly an error and the geographic ranges of the two species do not overlap.

Geographical distribution. Australia (Queensland), Papua New Guinea (Madang, Morobe, Sepik) (Fig. 12).

Type material examined. Holotype. Coelioxys weinlandi. PAPUA NEW GUINEA. Morobe. 1 ( $(\mathrm{BMNH})$, "Type", "B.M.TYPE, HYM., 17B.24". Syntypes. Coelioxys albiceps. PAPUA NEW GUINEA. Morobe. $3 \circ$ (ZMHB), "Neu Guinea, 1901, H. Kühn, Finschafen"; 1 + (ZMHB), idem, except "Coelioxys albiceps, 19 Friese Fr. det.", “Typus"; 1 ( (ZMHB), "Finschhafen, 1910, Hertle", "Coelioxys albiceps, 19 Friese Fr. det.". 


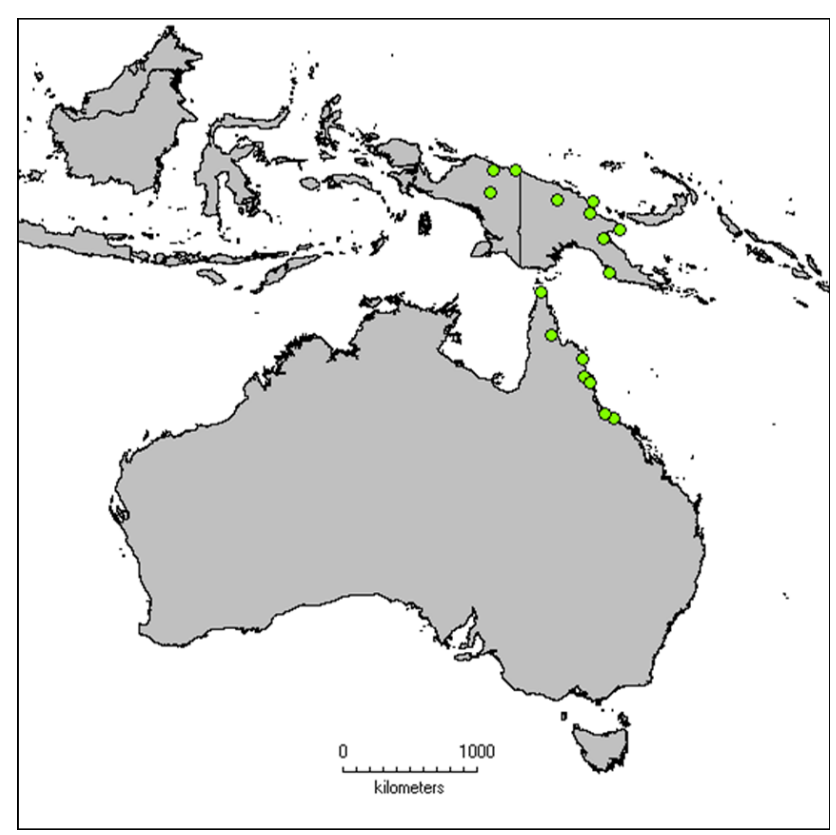

Fig. 12. Distribution records for Coelioxys weinlandi.

Additional material examined. AUSTRALIA. Queensland. 1 을 (AMS), Cooktown; $19(\mathrm{QM})$, Ayr; $1 \hat{\sigma}(\mathrm{QM})$, Meringa; 1 ㅇ (QM), "Kingfisher Park" 1 km N. of Julatten; 10 (SAM), Cairns dist.; $1 \widehat{\jmath}$ (MVMA), Coen; $1 \widehat{ }$ (WAM), Rowes Bay, Townsville. INDONESIA. Papua. $1{ }^{\hat{\alpha}}$ (BPBM), New Guinea: Wamena; 1 웅 (BPBM), New Guinea: Genjam, $40 \mathrm{~km} \mathrm{~W}$. of Hollandia; 1 9 (BPBM), New Guinea: Hol. Maffen, 22 km E. of Sarmi. PAPUA NEW GUINEA. East Sepik. 1 (QM), East Sepik Province, Amboin Patrol Post, Karawari Lodge. Madang. 19 (CAS), Madang Province: Karkar Island: Kevasop Village. Morobe. 1 우 (AMS), Bulolo; 1 오 (SAM), Wareo, Finsch Haven; 1 오 (SAM), Finsch Haven. National Capital District. $1+1 \overbrace{}^{\lambda}(\mathrm{BPBM})$, New Guinea: Port Moresby.

ACKNOWLEDGEMENTS. I would like to thank L. Packer for his critical reading and comments on the manuscript; D. Notton (BMNH), F. Koch (ZMHB), S.G. Brady and B. Harris (USNM), who allowed access to the holotypes; P.D. Perkins (MCZ), E. Wyman and J.G. Rozen (AMNH) who allowed access to the specimens in the collections under their jurisdiction; K. Walker (MVMA), D. Smith (AMS), P. Hudson (SAM), S. Wright (QM), N. Fischer and A. Landford (ANIC), N. Tatarnic (WAM), and V. Lee (CAS) who loaned the specimens used in this study. I also thank "Coordenação de Aperfeiçoamento de Pessoal de Nível Superior" (CAPES-CsF; grant no. 2502-13-5) for providing a scholarship; the Canadian Foundation for Innovation (CFI) and the Ontario Research Fund (ORF) through Canadensys for providing funds used to purchase all the equipment used to take the images.

\section{REFERENCES}

Australian Faunal Directory 2006 (by J.C. Cardale, 2001, updated by K.L. Walker, 2006): Hymenoptera: Apoidea. Australian Biological Resources Study, Canberra. http://www. environment.gov.au/biodiversity/abrs/online-resources/fauna/ afd/taxa/APOIDEA/checklist.htm/ (last accessed 10 October 2015).

Ascher J.S. \& Pickering J. 2015: Discover Life Bee Species Guide and World Checklist (Hymenoptera: Apoidea: Anthophila). http://www.discoverlife.org/mp/20q? guide=Apoidea species.htm/ (last accessed 10 October 2015).

Batley M. \& Hogendoorn K. 2009: Diversity and conservation status of native Australian bees. - Apidologie 40: 347-354.

Cockerell T.D.A. 1905: Descriptions and records of bees. I. Ann. Mag. Nat. Hist. (Ser. 7) 16: 216-225.

Cockerell T.D.A. 1911: The bees of the Solomon Islands. Proc. Linn. Soc. N. S. W. 36: 160-178.

Cockerell T.D.A. 1929: Bees from the Australian region. - Am. Mus. Nov. 346: 1-18.

Daly H.V. \& Magnacca K.N. 2003: Insects of Hawaii. Vol. 17. Hawaiian Hylaeus (Nesoprosopis) Bees (Hymenoptera: Apoidea). University of Hawai'i Press, Honolulu, 216 pp.

DIVA-GIS 2015: DIVA-GIS Program, Ver. 7.5. http://www.divagis.org/.

Friese H. 1909: Die Bienenfauna von Neu-Guinea. - Ann. Hist. Nat. Mus. Natl. Hung. 7: 179-288.

GonZalez V.H., Engel M.S. \& Griswold T.L. 2013: The lithurgine bees of Australia (Hymenoptera: Megachilidae), with a note on Megachile rotundipennis. - J. Melittology 11: 1-19.

LAtreille P.A. 1809: Genera Crustaceorum et Insectorum Secundum Ordinem Naturalem in Familias Disposita, Iconibus Exemplurisque Plurimis Explicata. Vol. 4. Koenig, Paris, 399 pp.

Michener C.D. 1965: A classification of the bees of the Australian and South Pacific regions. - Bull. Am. Mus. Nat. Hist. 130: $1-362$.

MichenER C.D. 2007: The Bees of the World. 2nd ed. The Johns Hopkins University Press, Baltimore, MD, 992 pp.

Mitchell T.B. 1973: A Subgeneric Revision of the Genus Coelioxys of the Western Hemisphere (Hymenoptera: Megachilidae). Department of Entomology, North Carolina State University, Raleigh, NC, $129 \mathrm{pp}$.

Rayment T. 1935: A Cluster of Bees. Sixty Essays on the LifeHistories of Australian Bees, with Specific Descriptions of over 100 New Species, and an Introduction by Professor E.F. Phillips, D.Ph., Cornell University, U.S.A. Endeavour Press, Sydney, $752 \mathrm{pp}$.

Schulz W.A. 1904: Ein Beitrag zur Kenntnis der papuanischen Hymenopteren-Fauna. — Berl. Entomol. Z. 49: 209-239.

Received July 9, 2015; revised and accepted October 13, 2015 Published online January 8, 2016 